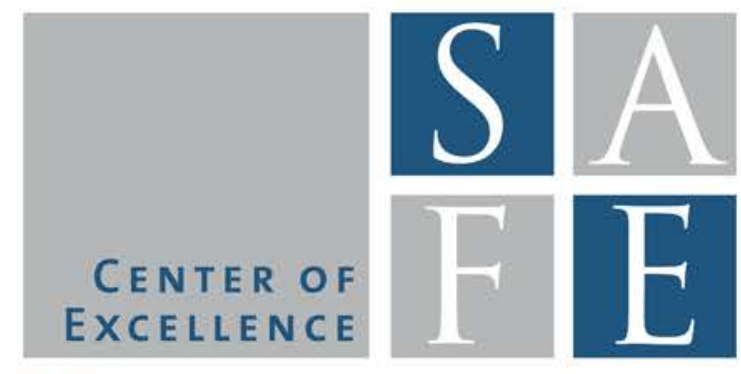

WORKING PAPER SERIES

Dirk Bursian - Sven Fürth

\title{
Trust Me! I am a European Central Banker
}

SAFE Working Paper Series No. 31

Center of Excellence SAFE Sustainable Architecture for Finance in Europe A cooperation of the Center for Financial Studies and Goethe University Frankfurt 


\section{Non-Technical Summary}

Trust in central banking has become increasingly important to practitioners. Recently, the Eurosystem, as well as other monetary systems around the globe, has experienced a significant number of unconventional monetary policy measures. Besides keeping interest rates on the main refinancing operations historically low, the Governing Council of the European Central Bank (ECB) inter alia decided to intervene in the bond market through secondary market operations in order to combat the crisis. These interventions have been subject to substantive criticism saying that such bond purchases violate the ECB code of conduct. Here the question arises whether such unconventional measures do indeed run the risk of worsening the credibility of the ECB or benefit the trust-building process by stabilizing or even fostering good macroeconomic conditions. Hence, a systematic investigation of the drivers of trust in the ECB is desirable.

We provide new evidence into which factors determine trust in central banking. We use a unique cross-country dataset based on Eurobarometer survey data covering the years 1999 to 2010 which includes a rich set of socio-economic characteristics. We then supplement it with variables meant to reflect a country's macroeconomic condition as well as regional developments. We find that besides individual socio-economic characteristics, macroeconomic conditions play a crucial role in the trust-building process which constitutes boundedly rational behavior in the trust-building process. Factors that are outside the control of the ECB should be irrelevant for the trust-building process of fully rational agents which is, however, not supported by our analysis.

Overall, our results suggest that trust in the ECB can be strengthened by an improvement in general macroeconomic conditions in European countries. Therefore, current ECB market interventions may have positive effects on the overall level of trust in the long-run through strengthening and stabilizing effects on the European markets and the European economy in general. 


\title{
Trust Me! I am a European Central Banker*
}

\author{
Dirk Bursian $^{\dagger}$ and Sven Fürth ${ }^{\star}$
}

This version: June 2012

\begin{abstract}
In the aftermath of the financial crisis, the ECB has experienced an unprecedented deterioration in the level of trust. This raises the question as to what factors determine trust in central banking. We use a unique cross-country dataset which includes a rich set of socioeconomic characteristics and supplement it with variables meant to reflect a country's macroeconomic condition. We find that besides individual socio-economic characteristics, macroeconomic conditions play a crucial role in the trust-building process. Our results suggest that agents are boundedly rational in the trust-building process and that current ECB market operations may even be beneficial for trust in the ECB in the long-run.
\end{abstract}

JEL-Classification: D1, E5, G21, H6.

Keywords: Central Banking, European Central Bank, Financial Crisis, Fiscal Crisis, Trust.

* We would like to thank Ester Faia, Stefan Goldbach, Reint Gropp, Martin Karlsson, Fabrizio Mattesini, Markus Roth, Mark Wahrenburg, and the participants of the XX International Tor Vergata Conference on Money, Banking, and Finance and the 2012 Global Conference on Business and Finance for useful comments. Bursian and Fürth acknowledge partial financial support by the Vereinigung von Freunden und Förderern der Johann Wolfgang Goethe-Universität e.V.. An earlier version of the paper was titled "Trust in the European Central Bank: The Role of Macroeconomic Performance, Regional Developments, and the Crisis". All errors are ours.

$\dagger$ Goethe University Frankfurt, Chair for Monetary and Fiscal Policy, House of Finance, Grueneburgplatz 1, 60323 Frankfurt am Main, Germany. E-mail: dirk.bursian [at] hof.unifrankfurt.de.

\$ Goethe University Frankfurt, Chair of Banking and Finance, House of Finance, Grueneburgplatz 1, 60323 Frankfurt am Main, Germany. E-mail: sven.fuerth [at] hof.unifrankfurt.de. 


\section{INTRODUCTION}

Trust in central banking has become increasingly important to practitioners. Recently, the Eurosystem, as well as other monetary systems around the globe, has experienced a significant number of unconventional monetary policy measures. Besides keeping interest rates on the main refinancing operations historically low, the Governing Council of the European Central Bank (ECB) inter alia decided to intervene in the bond market through secondary market operations in order to combat the crisis. These interventions have been subject to substantive criticism ${ }^{1}$ saying that such bond purchases violate the ECB code of conduct. $^{2}$ Here the question arises whether such unconventional measures do indeed run the risk of worsening the credibility of the ECB or benefit the trust-building process by stabilizing or even fostering good macroeconomic conditions. Hence, a systematic investigation of the drivers of trust in the ECB is desirable.

The main aim of this paper is to provide new evidence on the drivers of trust in the ECB. In this context, we explore not only the importance of socio-economic characteristics, but also the effect of overall macroeconomic conditions during crisis and non-crisis periods.

Our analysis consists of five parts. In the first part we shed light on the question as to what extent trust in the ECB is driven by individual socio-economic characteristics. We then supplement our dataset with variables meant to reflect a country's macroeconomic condition in order to explain the observed differences in the level of trust between countries. It might be argued that those results are mainly driven by the occurrence of the financial crisis and the recent recession. To counter this objection, we augment our regression specification in a third step and control for the recent recession individually which allows us to shed light on the role of the crisis in the trust-building process. In a fourth step, we show that the relative importance of our macroeconomic variables increased during the crisis, suggesting that people are even more attentive to changes in macroeconomic conditions during economic downturns as might be expected. In what follows, we focus our attention on the role of regional developments net of countrywide differences as recent studies have shown that modeling within-country heterogeneity is important in the context of, for instance, financial

\footnotetext{
${ }^{1}$ See for instance Dombret (2011) and Weber (2011).

${ }^{2}$ According to $\S 123$ (1) of the Treaty on the European Union (see for instance Foster, 2011), only direct purchases of government bonds are forbidden, not purchases through the secondary market which provided a legal backdoor for the ECB to intervene.
} 
integration (Ekinci et al., 2009), participation in financial markets (Guiso et al., 2004), and household repayment behavior (Georgarakos and Fürth, 2010).

\section{LITERATURE REVIEW}

The issue of trust or social capital in general is important both in sociology and in economics. Durlauf and Fafchamps (2004) review empirical studies and identify key features of social capital. Among those key features are externalities that are generated through shared trust, values, and norms. La Porta et al. (1997) find evidence that trust is negatively associated with corruption, but influences the justice system and the quality of bureaucracy positively. Similarly, Uslaner (2004) points out that trust and corruption are negatively associated.

Concerning economic activity, Georgarakos and Pasini (2011) find that higher levels of trust are positively associated with stock market participation. In particular, they show that the effect of trust is stronger for wealthier households in certain European countries where stock market participation is limited and average levels of trust are low. Also, Georgarakos and Fürth (2010) examine household repayment behavior in Europe and point out that there is a strong correlation between a bad repayment behavior and living in regions with low prevailing levels of trust. Furthermore, Tabellini (2010) shows that key determinants of differences in economic developments across European regions are regional differences in values and norms, for instance measured by regional trust, whereas Guiso et al. (2004) find evidence that individuals who live in Italian regions with low social capital are more likely to obtain loans from friends and relatives. Trust also plays an important role for economic growth. Studies by, for instance, Zak and Knack (1999) and Knack and Keefer (1997) show that higher prevailing trust has a positive impact on economic growth.

We now turn to the rationale behind the association of trust with monetary policy or central banking in general. Barro and Gordon (1983) highlight, from a theoretical point of view, the essential role of credibility and reputation of central banks for the conduct of monetary policy. They show that discretionary monetary policy, in other words the ability of the central bank to reoptimize each period, leads to an inflationary bias. That is to say that the inflation rate will be higher than the one that is socially desirable. As credibility and trust are closely connected, it is difficult to disentangle them. Rogoff (1985) proposes the appointment of a conservative central banker who is more inflation-averse than society as a whole in order to overcome the inflationary bias. In a similar way, Walsh (1995) argues that performance contracts are able eliminate the inflationary bias. In both cases, however, the issue of 
credibility and trust is still predominantly important as the public must be convinced that in fact a more conservative central banker has been appointed or that the performance contract is feasible and/or implementable, respectively.

Furthermore, Clarida et al. (1999) show that expectation management is important in dynamic New Keynesian modeling. In the absence of cost-push and demand shocks, it can be shown that inflation is determined solely by the evolution of expected future output gaps, whereas the output gap in return is determined solely by the expected future paths of oneperiod real interest rates. Hence, both output gap and inflation are forward-looking variables. The public's expectations are clearly influenced by the issue of trust in the ECB which therefore actively tries to influence the formation of market expectations inter alia by signaling the future path of monetary policy through press conferences and keynote speeches.

Despite the importance for central banks of how they are perceived by the public and especially the deterioration in the level of trust in the ECB during and after the financial crisis, there have been only a few studies that find empirical evidence for the determinants of these perceptions. For example, Fischer and Hahn (2008) study the determinants of trust from 1999 to 2004 by using aggregated annual data and find that lower inflation and higher national income increases trust in the ECB. Gros and Roth (2010) use aggregated semi-annual data on trust in the ECB from 1999 to 2009 and find that only GDP growth has had a strong positive impact during the financial crisis. Those studies, however, are limited. First, they do not take account of the fact that there is an inherently subjective component in whether or not individuals have trust in the ECB. Neither study controls for heterogeneity in trust among households with different characteristics using micro-level data which we show are important drivers of trust. Therefore, we would expect omitted variables to be a problem in their regression specifications whenever any of the covariates under consideration is correlated with the omitted socio-economic characteristics. Consequently, the results presented in Fischer and Hahn (2008) and Gros and Roth (2010) capture correlations rather than true causal relations. Second, no light is shed on the mechanism underlying the trust-building process. Third, as we will show in our study, regional developments also play an important role in determining trust in the ECB and have to be taken into account.

\section{DETERMINANTS OF TRUST IN THE EUROPEAN CENTRAL BANK}

\subsection{Data Sources and Descriptive Statistics}


We use data from Eurobarometer surveys which are conducted on behalf of the European Commission at least twice a year in all European Union (EU) member states. The surveys cover a rich set of demographic characteristics in order to monitor the social and political attitudes of households in the EU. More specifically, we combine a selected set of 25 Eurobarometer surveys in order to build a semi-annual repeated cross section from 1999 to $2010 .{ }^{3}$ Hence, we include the most recent survey data that is available. One strength of the surveys is that several questions on attitudes towards European institutions are asked at least twice a year, which makes it possible to construct the variable of interest, perceived trust in the ECB, in all datasets. Specifically, the surveys ask the participants:

"And, for each of them, please tell me if you tend to trust it or tend not to trust it? (READ OUT): The European Central Bank“.

The survey participants are then given the choice between the three possible answers: "1, Tend to trust", "2, Tend not to trust", and "3, Do not know".

The national level of trust is calculated as the relative share of survey participants in each national sample who answer " 1 , Tend to trust" to the question above. Figure 1 presents the mean response regarding trust in the ECB from 1999 to 2010 for selected EMU member countries used in the study ${ }^{4}$. There are two main observations. First, with the start of the financial crisis, the selected countries experienced a substantial reduction in the mean level of trust in the first half of 2009. Second, the mean levels of trust show a substantial variation over time as well as across the selected EMU member countries. Consequently, we present the mean levels of trust in the ECB for all of our EMU member countries for the whole time period from 1999 to 2010 in table 1. Starting with the first half of 1999, the lowest level of trust in the ECB prevailed in France with the highest level of trust prevailing in the Netherlands. Overall, mean levels of trust are quite heterogeneous across different countries and also different time periods and not all countries experienced an immediate drop in the level of trust at the start of the financial crisis. Therefore, the overall decline in trust cannot be explained solely by the occurrence of the financial crisis. However, as the crisis was heating up, the level of trust dropped in almost all of the countries under consideration. The lowest level of trust was reached in the second half of 2010 in Greece. One might argue that this is

\footnotetext{
${ }^{3}$ A detailed description of the several datasets used can be found in the Appendix.

${ }^{4}$ The following countries are used in our study: Austria, Belgium, Finland, France, Germany, Greece, Ireland, Italy, Luxembourg, Netherlands, Portugal, and Spain.
} 
not surprising in the light of the ECB's current interventions in Greece and in particular the ongoing fiscal crisis.

Those descriptive statistics, however, have to be interpreted with caution. Lower mean levels of trust in one country compared to another one might also be driven by a variety of other factors. In what follows, we try to identify those factors that drive the observed differences in the level of trust between countries over time. Therefore, we use a rich set of socio-economic characteristics and combine those with variables meant to reflect a country's macroeconomic condition and regional developments. Here we consider national real GDP growth, inflation deviations from the target level, government debt as a share of GDP, one year government bond yield spreads over German bonds, and the unemployment rate. Regional GDP growth and the regional unemployment rate are used as regional indicators. Table 2 contains summary statistics for the variables under consideration for the whole sample as well as the samples corresponding to the crisis and non-crisis period, respectively. National real GDP growth rates are calculated based on a seasonally adjusted chain-linked quarterly real GDP time series. We argue that the average annual change of the Harmonized Index of Consumer Prices (HICP) is the relevant measure of inflation as it represents the principal measure of inflation that the citizens are mostly confronted with for instance in media coverage. Also, we argue that it is not absolute HICP inflation that is relevant for the determination of trust in the ECB and use absolute inflation deviations from the target level as potential determinants ${ }^{5}$. Government debt is measured as the absolute government debt level relative to each country's national GDP whereas the yields of one year government bonds with constant maturity are used in order to calculate the government bond yield spread over German bonds. The unemployment rate refers to the average national unemployment rate within the respective semester. A more detailed variable description can be found in table 3 .

\subsection{The Role of Socio-Economic Characteristics}

\footnotetext{
${ }^{5}$ The ECB does not claim to target inflation. However, it has adopted an implicit inflation target of below but close to 2 percent. Therefore, it is reasonable to believe that the response of trust in the ECB to changes in inflation is not homogenous across the whole support of inflation. Rather, we would expect the sign of the response to be different to the left and to the right of the implicit inflation target. In addition, this approach is theoretically more appealing as it is in line with the quadratic-linear approach as presented for instance in Walsh (2010) and a central bank loss function that penalizes the central bank when realized inflation differs from the target level of inflation.
} 
In all subsequent analyses, we estimate a series of probit models. The probability that an individual has trust in the ECB in a certain period is expressed as a function of various socio-economic characteristics. Those characteristics include age, gender (male; with females forming the reference group), marital status (couple, single, divorced; with the widowed forming the reference group), employment status (self-employed, retired, unemployed; with employees forming the reference group), and educational attainment (high school degree, college degree; with those who did not complete high school forming the reference group).

In table 4 (1) we present the results for the socio-economic characteristics. In table 4 (2) we additionally include country fixed effects which absorb most of the countrywide differences. The results are qualitatively similar even after controlling for potentially omitted countrywide variables. Being a couple (single) compared to being widowed increases the probability of trust in the ECB by 3.5 (1.5) percent. Males have a 2.8 percent higher probability of trust compared to females. The probability of trust in the ECB of retired (unemployed) citizens is reduced by 1.5 (3.1) percent. The better educated individuals are, the more likely it is that they have trust in the ECB. A high school degree increases the probability of trust in the ECB by 3.5 percent compared to those individuals not having completed high school. For college graduates the effect is even stronger with 11.3 percent. Therefore, educational attainment seems to play the most important role among the individual socio-economic characteristics. These results are in line with Glaeser et al. (2000) who find that being male, married, and college educated increases trust. As an additional indicator, we consider the political views of the individuals. We find that individuals whose political views are more to the left of the political spectrum are less likely to show trust in the ECB. This result is in line with the findings of Algan and Cahuc (2009) who study the impact of civic attitudes on labor markets. They show that people with left-wing political views find it more justifiable to claim state benefits for which they are not eligible than those with right-wing political views. Moreover, the country dummies are mostly significant in this specification. Thus, national characteristics seem to influence the probability of trust in the ECB significantly. The omitted category here is Germany. For example, the probability of trust of French citizens is on average 11.6 percent lower compared to German citizens. For Dutch 
citizens, on the other hand, the expected probability of trust increases by the substantial amount of 13.2 percent. This shows that not controlling for between-country heterogeneity would lead to misleading results. In what follows, we try to identify to what extent differences in macroeconomic conditions drive the observed differences in the level of trust between countries over time.

\subsection{The Role of Macroeconomic Conditions}

We now add variables meant to reflect a country's macroeconomic condition. These variables are national real GDP growth (GDP Growth), absolute inflation deviations from the target level (Inflation deviation), and the national unemployment rate (Unemployment Rate). Furthermore, two variables that are related to sovereign debt are included. Those variables are government debt as a share of national GDP (Government Debt) and one year government bond yield spreads over German bonds (Government Bond Spread).

One would expect variables that are not related to the ECB's mandate or are outside its control to be irrelevant for the trust-building process. However, if we assume that agents are boundedly rational and do not fully understand the mandate of the $\mathrm{ECB}$, they might be influenced by such factors as well. For a comprehensive overview of the literature on behavioral finance, see Barberis and Thaler (2002).

People might associate good economic performance measured by real GDP with personal welfare. Furthermore, good economic conditions in general which may be reflected by GDP growth turn out to be beneficial for the public as, for instance, already employed people are more likely to benefit through performance bonuses or incentive schemes. In a similar way, a high level of real GDP as a proxy for national income might be regarded as an indicator for the well-functioning as well as the efficiency of different economic institutions in line with La Porta et al. (1997). As well-functioning institutions and a high level of efficiency are desirable, public perceptions may also be adjusted positively. Therefore, we include real GDP growth even though full rationality would imply no significant response of trust in the ECB to changes in this variable.

The only variable in our study which is closely related to the ECB's mandate concerns inflation deviations from the target level. The ECB's primary objective of price stability is outlined in $\S 127$ of treaty on the European Union. High inflation deviations from the target 
level might therefore suggest that the ECB is not capable of ensuring price stability or, more seriously, is not following its mandate. Hence, if the public understood the mandate of the $\mathrm{ECB}$, inflation deviations from the target level should be among the most important determinants in the trust-building process. Consequently, one would expect this variable to be strongly negatively related to trust in the ECB.

Relative government debt is restricted by the treaty on the European Union in $\S 126$. By $\S 126$ (2), the development on the budgetary situation and the stock of government debt shall be monitored by the European Commission and not by the ECB. Here, again, if agents do not fully understand that the ECB is not responsible for monitoring government debt, they may associate the financial situation in their home country represented by relative government debt with European institutions such as the ECB. Hence, we include relative government debt in our study.

Government bond yield spreads are determined by various factors such as credit risk which reflects default risk, credit spread risks, and downgrade risk. In this respect, the financial crisis had a significant impact on all of these 3 factors due to a weakening of the fiscal position resulting from, for instance, high costs for financial rescue packages and fiscal stimuli. Bernoth et al. (2004) find that debt sustainability has a significant positive impact on sovereign spreads. As we separately control for relative government debt and therefore longrun sustainability in the spirit of Sturzenegger (2002), our variable does not reflect a change in debt sustainability. Moreover, the downgrade of several countries had a direct impact on the portfolio allocation of institutional investors since they mostly have only limited investment possibilities depending on the respective credit rating. The second factor is liquidity risk, in other words the risk that a certain asset cannot be traded as quickly as desired. However, Pagano and von Thadden (2004) and Favero et al. (2005) show that such liquidity premia in the European market almost vanished with the start of the EMU. De Santis (2012) shows that even in the current fiscal crisis, liquidity factors only play a minor role.

We do not intent to specifically break down the different impact factors mentioned above such that our results for the government bond yield spreads over German bonds could still reflect a combination of those factors as well. We follow the approach that the public opinion about the institutional dealing is shaped by an aggregated observable measure such as government bond yield spreads. Especially the recent crisis and frequent reports about changes in those spreads in combination with secondary market operations performed by the 
ECB starting mid- $2009^{6}$ may have shaped public perceptions about the efficiency of institutional dealings significantly. As we will show, the public seems to associate such government bond yield spreads negatively with the ECB.

Despite already controlling for the individual employment status, we assume that agents' perceptions are also shaped by the overall unemployment rate which can be thought of as a proxy for the unconditional probability of becoming unemployed. Hence, we include the unemployment rate in our study.

Note that an endogeneity problem might arise because of simultaneous trust in the ECB and, for example, contemporaneous real GDP growth as studies have shown that trust plays an important role in determining a country's economic growth. Zak and Knack (1999) and Knack and Keefer (1997) show that higher prevailing trust has a positive impact on growth. In order to overcome this problem, we perform regression analyses on lagged macroeconomic variables. In such a way, we rule out reverse causality and a bias resulting from simultaneity. This approach is, moreover, appealing because it is reasonable to assume that the public does not respond contemporaneously to changes in the covariates previously mentioned but is more likely to base its judgment of whether or not to trust the ECB on their experience in the recent past.

In order to shed light on the importance of macroeconomic conditions, we include the corresponding variables in our study in table 5. We first run a separate regression for each of the five macroeconomic variables under consideration. The results for those specifications can be found in table 5 (1) up to (5). Subsequently, we include in table 5 (6) all of the five variables in order to simultaneously control for a country's macroeconomic condition. In the augmented specification, the macroeconomic variables are almost all significant at the 1 percent level. Our results show that real GDP growth has a positive impact on trust whereas relative government debt, government bond yield spreads, and the unemployment rate influence trust negatively. More specifically, an increase in real GDP growth by 1.0 percent implies a 1.0 percent increase in the probability of trust in the ECB. An increase in relative government debt reduces the expected probability of trust. For example, an increase in Italian relative government debt from around 106 percent in 2008 to around 119 percent in 2010 would ceteris paribus imply a decline in trust of around 1.3 percent. With regard to government bond yield spreads, the expected probability decreases by 3.0 percent given an

\footnotetext{
${ }^{6}$ See http://www.ecb.europa.eu/ecb/legal/pdf/1_17520090704en00180019.pdf for the decision of the ECB on the implementation of the covered bond purchase program.
} 
increase in the spread by 1 percent. An increase in the unemployment rate by 1 percent implies a 1.2 percent reduction in the probability of trust in the ECB. Surprisingly, inflation deviations from the target level do not seem to play a role in the trust-building process once macroeconomic conditions are controlled for. The findings concerning the effects of the individual socio-economic characteristics are qualitatively similar even after controlling for a country's macroeconomic condition. The estimated coefficients are similar in significance, sign, and magnitude.

One might argue that the results presented so far are driven by the fact that some survey participants were simply not aware of the ECB and its mandate. Therefore, one question that is also frequently asked in Eurobarometer surveys proved to be very useful in that respect. The survey asks participants:

\section{"Have you heard of the European Central Bank?"}

As before, the survey participants are then given the choice between the three possible answers: "1, Yes", "2, No", and "3, Do not know". Those survey participants who answer the question above with "2, No" or "3, Do not know" have never heard about the ECB or are not sure about the answer to this question. We would expect the responses of these survey participants to the question of whether or not they have trust in the ECB to partly have a random nature rather than being based on a profound judgment. In this context, the responses to the question above allow us to run the same regressions again for a subsample of observations only. More specifically, we run regressions for the subsample of people who actually have heard about the ECB, in other words for those participants who answered the question above with "1, Yes". We can thus reduce the random nature of the responses of survey participants regarding the question of trust in the ECB to a minimum. The results presented before are still confirmed. With the exception of the coefficient on inflation deviations, the estimated coefficients are similar in significance, sign, and magnitude. Trust shows a significant negative response to a change in inflation deviations from the target level. Hence, the ECB's performance concerning its mandate seems to influence the trust-building process only when looking at the subsample of people who actually have heard about the ECB and not the overall sample. This seems reasonable from an intuitive point of view and highlights the importance of ECB communication.

In fact, our results suggest that agents are boundedly rational in the trust-building process. First, variables that are either in the short-run or in the long-run outside the control of 
the ECB like, for instance, real GDP growth should be irrelevant for the trust-building process of fully rational agents which is not supported by our analyses. Second, one would expect fully rational forward-looking agents to be more strongly focused on long-run sustainability issues of government debt in the spirit of Sturzenegger (2002) rather than, for instance, on short-run credit risk. This, however, is also not supported by our analysis. We find that agents seem to put more weight on short-run credit risk in the trust-building process reflected by the substantial difference in the marginal effects.

\subsection{A Structural Break in Trust During the Crisis}

As shown in figure 1, the mean levels of trust of selected EMU member countries underwent a significant drop in the first half of 2009. In order to check whether the results presented so far are potentially driven by the recent recession, we additionally include a dummy variable ${ }^{7}$ that is capable of shifting the probability of trust in the ECB regardless of the values of the covariates.

The results presented in this section are summarized in table 6. We find that our previous results are robust to the change in the specification. The financial crisis had a negative impact on the probability of trust in the ECB as expected. When all our macroeconomic variables are included, the coefficient corresponding to the crisis dummy is significant at the 1 percent level and implies that the probability of trust was reduced by 2.0 percent during that time period. This confirms that there was an overall significant reduction of trust in the ECB during the financial crisis net of differences in macroeconomic conditions and socio-economic characteristics.

The results concerning our macroeconomic variables are robust to our change in the specification. The coefficients on real GDP growth, absolute inflation deviations from the target level, relative government debt, government bond yield spreads, and the unemployment rate are of similar significance and imply qualitatively similar responses compared to the results presented in the previous section. More specifically, an increase in real GDP growth by 1 percent implies a 0.8 percent increase in the probability of trust in the ECB. An increase in relative government debt, however, leads to an expected reduction in the probability of

\footnotetext{
${ }^{7}$ Dating such a dummy variable is somewhat arbitrary. In order to present a transparent and coherent way of generating the dummy, we closely follow the Center for Economic Policy Research (CEPR) Business Cycle Dating Committee (see http://www.cepr.org/data/dating/). The Committee has identified a recession starting in 2008 quarter 1 and lasting until 2009 quarter 2. Consequently, we date the recession accordingly.
} 
having trust by 0.1 percent. Where bond yield spreads are concerned, the expected probability decreases by 3.0 percent given an increase in the spread by 1 percent. An increase in the unemployment rate leads to a reduction in the probability of trust by 1.2 percent. The response of trust in the ECB to changes in inflation deviations from the target level is also not affected. The findings concerning the effects of the individual socio-economic characteristics are again qualitatively similar even after controlling for a country's macroeconomic condition and the incidence of the recent recession.

\subsection{The Role of Macroeconomic Conditions During the Crisis}

In the previous sections, we presented the impact of several socio-economic characteristics and macroeconomic variables on trust in the ECB. Moreover, we controlled for the recent recession separately using a dummy variable that showed a significant negative impact on the probability of trust of around 2.0 percent. In what follows, we aim at identifying the relative importance of our macroeconomic variables during the crisis. In order to do this, we interact the variables we are interested in with the crisis dummy previously introduced. However, this has to be done with caution since our dependent variable is a binary variable and we model trust in the ECB in a nonlinear way. In recent years, there has been extensive discussion about how to interpret interaction effects in such nonlinear models in terms of marginal effects. A common mistake is to interpret the first derivative of the interaction term of two explanatory variables as the interaction effect. This is misleading as the interaction effect is represented by the cross partial derivative of both interacted variables which can be different from the first derivative in nonlinear models. This makes the calculation of interaction effects in nonlinear models a cumbersome task. Cornelißen and Sonderhof (2009) show how to interpret and calculate the effects of triple dummy variable interactions whereas Buis (2010) shows how to interpret interaction effects using multiplicative effects such as, for example, odds ratios, incidence-rate ratios, or hazard ratios.

We follow the methodology provided by Norton et al. (2004). Ai and Norton (2003) show that interaction effects in probit or logit models cannot be adequately computed using standard software packages and do not represent the true interaction effects. They show that the true effects can be of different magnitude and even of different sign. Standard inference is therefore problematic. One downside to their approach is that it is only possible to calculate one interaction effect at a time, precluding the inclusion of more than one interaction term simultaneously. In addition to the mean interaction effect, we provide a graphic illustration to 
show the full set of interaction effects. To the best of our knowledge, there is still no other valid technique for calculating more than one interaction effect at a time. We ran regression (6) in table 6 again and included the dummy variable corresponding to the recent recession as before as well as an interaction term of the macroeconomic variable under consideration with the dummy. This provides useful insights into how the response of trust in the ECB to changes in any of the covariates mentioned before changes in times of crisis. The results presented in this section are summarized in table 7.

The influence of real GDP growth increased during the crisis. We conclude that an increase in real GDP growth by 1 percent during the crisis increased the probability of trust on average by 1.1 percent more compared to non-crisis times. In times of crisis, the public seems to be more aware of economic conditions and adjust their judgment accordingly. Figures 2 and 3 show the complete distribution of interaction effects and z-statistics, respectively. It can be seen that the interaction effects are in all cases larger than zero with the $\mathrm{z}$-statistic always exceeding 5.0. Therefore the interaction effects are highly significant.

We conclude from the interaction study that the influence of inflation deviations from the target level remained unchanged during the crisis as the interaction effects are in all cases negative but insignificant. Figures 4 and 5 show the complete distribution of interaction effects and z-statistics, respectively.

Furthermore, the interaction effects of relative government debt are highly significant and negative. Figures 6 to 7 show the complete distribution of the interaction effects and zstatistics, respectively. We find that the interaction effect is on average minus 0.2 percent.

The interaction effects of the government bond yield spreads over German bonds are highly significant and negative. Figures 8 to 9 show the complete distribution of the interaction effects and z-statistics, respectively. We find that the interaction effect is on average minus 5.8 percent. Hence, the associated information effect of government bond spreads concerning the efficiency of the ECB due to, for instance, higher media coverage, seemed to increase. However, we have to take into account that in the case of Greece and maybe other European countries, government bond yield spreads might also measure liquidity effects. During the crisis, the ECB temporarily lowered the required rating of collaterals in liquidity provisions. At the end of 2009, it announced that the pre-crisis minimum rating would be reestablished in 2011. This increased the future liquidity risk for instance for Greek bonds which were rated $\mathrm{BBB}+$ at this time. Here, we might measure a negative reaction of the 
public to such a change in the policy as this change may have increased the uncertainty of market participants in the bond markets and therefore worsened sovereign spreads. Moreover, the increase in the effect of government bond yield spreads might be stronger due to the secondary market operations performed by the ECB which were not always successful in lowering sovereign spreads and therefore may not have been trust-building. However, such negative effects on trust in the short-run do not necessarily have to be trust-reducing in the future. In the long-run perspective, trust-building spill-over effects resulting from higher economic growth, lower unemployment rates, and the stabilization of the bond markets could potentially outweigh such a current negative effect.

Finally, we consider the interaction effect of the unemployment rate. It can be seen that the interaction effects are in all cases smaller than zero and highly significant with the zstatistic always being smaller than minus 2.0. Figures 10 and 11 show the complete distribution of the interaction effects and z-statistics, respectively.

Our results suggest that the relative importance of our macroeconomic variables increased during the crisis. We conjecture that this effect is due to an increase in public awareness of the prevailing economic conditions during the crisis and in economic downturns in general. Only for inflation deviations from the target level, the trust response remained unchanged during the crisis.

\subsection{The Role of Within-Country Heterogeneity}

Households living in the same country might still differ in their perception due to differences in the local environments, local developments in that specific country, or their satisfaction with the work of regional political parties. For instance, households living in different regions can have different attitudes towards the ECB driven by different local developments. Guiso et al. (2004), for instance, show that individuals who live in Italian regions with low social capital are more likely to obtain loans from friends and relatives. Or Ekinci et al. (2009) show that limited financial integration within and between European countries and regions is quite different. Following Tabellini (2010), the key determinants of differences in economic developments across European regions are regional differences in values and norms. Therefore, trust in the ECB, our key variable of interest, is likely to be influenced by such differences as well. 
In the context of modeling within-country heterogeneity, it is essential to present a uniform and consistent breakdown of territorial units in order to generate the necessary regional statistics. In our study, we use the Nomenclature of Territorial Units for Statistics (NUTS) which was introduced for the EU by Eurostat. ${ }^{8}$

The results presented in this section are summarized in table 8 where we show that regional GDP growth as well as the regional unemployment rate are significant determinants of trust in the ECB. In table 8 (1) we present the results for the regional indicators. We additionally include country fixed effects in table 8 (2) which absorb most of the countrywide differences. The coefficients are significant and imply that an increase in regional GDP growth results in an expected increase in the probability of trust by 0.1 percent. Concerning the regional unemployment rate, the expected probability of trust is reduced by 0.3 percent given an increase in the regional unemployment rate by 1 percent. Unfortunately, due to limited data availability concerning regional GDP growth as well as the regional unemployment rate, we cannot simultaneously control for regional developments measured in terms of both variables and overall macroeconomic conditions. This would require us to leave out a substantial amount of data which we try to avoid whenever possible. However, recall that we include country fixed effects in table 8 (2) which control for most of the heterogeneity between the EMU member countries.

\section{CONCLUSION}

We provide evidence for the main drivers of trust in the ECB using a unique crosscountry dataset covering the years 1999 to 2010 which we supplement with variables meant to reflect a country's macroeconomic condition as well as regional developments.

\footnotetext{
${ }^{8}$ The NUTS has a hierarchical order. Consequently, the NUTS 1 definition is the broadest definition and those regions include NUTS 2 and NUTS 3 regions and so forth. In what follows, we provide the minimum and maximum thresholds for the approximate size of each NUTS region. A minimum of 3 million and a maximum of 7 million holds true for the NUTS 1 level. For NUTS 2 regions, the minimum size is 0.8 million and the maximum 3 million whereas NUTS 3 regions have a minimum size of 0.15 million and a maximum size of 0.8 million. We use the NUTS 2 definition from Eurostat in most cases and we end up with a total of 63 European regions for our 12 EMU member countries.
} 
Our results suggest that individual socio-economic characteristics are relevant in determining trust in the ECB. We show that inter alia the employment status, educational attainment, and an individual's political orientation are central factors in explaining the variation in our dependent variable.

Variables meant to reflect macroeconomic conditions are able to explain trust in the ECB in a significant way which constitutes boundedly rational behavior. First, variables that are either in the short-run or in the long-run outside the control of the ECB like real GDP growth should be irrelevant for the trust-building process of fully rational agents. This, however, is not supported by our analyses. Second, we include relative government debt and government bond yield spreads over German bonds which are closely related to sovereign debt. We find that agents seem to put more weight on short-run credit risk in the trust-building process rather than on the long-run sustainability of government debt reflected by a substantial difference in the marginal effects. This is counterintuitive as one would have expected fully rational forward-looking agents to be more strongly focused on long-run sustainability issues.

Consumer price stability as defined by the ECB does not seem to influence the trustbuilding process significantly. We find that the ECB's performance concerning its mandate is only relevant for the trust-building process when looking at the subsample of people who actually have heard about the ECB. This highlights the predominant role of communication and expectations management in general for the conduct and the effectiveness of monetary policy. Hence, it is advisable to intensify ECB communication to the public and in particular to people outside the economics profession or related areas.

Finally, we present a uniform and consistent breakdown of territorial units in line with the NUTS nomenclature provided by Eurostat in order to model heterogeneity within countries. The statistical significance of regional as well as national variables suggests that both regional and country-specific developments are important for the determination of trust. It is up to future research to further investigate the importance of regional development in addition to the results concerning regional GDP growth and the regional unemployment rate as presented as soon as more data for regional indicators is available. 
Overall, our results suggest that trust in the ECB can be strengthened by an improvement in general macroeconomic conditions in European countries. Therefore, current ECB market interventions may have positive effects on the overall level of trust in the longrun through strengthening and stabilizing effects on the European markets and the European economy in general. It remains to be seen in the future whether the loss of trust resulting from potential deviations from the ECB mandate which are currently put forward by economists and policy makers alike can be outweigh by positive spill-over effects through potentially higher economic growth, lower unemployment rates, and stabilizing effects on the bond markets. 


\section{REFERENCES}

Ai, Chunrong, and Edward Norton, "Interaction Terms in Logit and Probit Models", Economics Letters 80 (2003), 123-129.

Algan, Yann, and Pierre Cahuc, "Civic Virtue and Labor Market Institutions", American Economic Journal: Macroeconomics 1:1 (2009), 111-145.

Barberis, Nicholas, and Richard Thaler, "A Survey of Behavioral Finance”; NBER Working Papers No. 9222 (2002).

Barro, Robert, and David Gordon, "Rules, Discretion and Reputation in a Model of Monetary Policy”, Journal of Monetary Economics 12 (1983), 101-122.

Bernoth, Kerstin, Jürgen von Hagen, and Ludger Schuknecht, "Sovereign Risk Premia in the European Government Bond Market”, ECB Working Paper Series No. 369 (2004).

Buis, Marten, "Interpretation of Interactions in Non-Linear Models", The Stata Journal 10:2 (2010), 305-308.

Clarida, Richard, Jordi Gali, and Mark Gertler, "The Science of Monetary Policy: A New Keynesian Perspective”, Journal of Economic Literature 37 (1999), 1661-1707.

Cornelißen, Thomas, and Katja Sonderhof, "Partial Effects in Probit and Logit Models with a Triple Dummy-Variable Interaction Term", The Stata Journal 9 (2009), 571-583.

De Santis, Roberto, "The Euro area sovereign debt crisis: safe haven, credit rating agencies and the spread of the fever from Greece, Ireland and Portugal", ECB Working Paper Series No. 1419 (2012).

Dombret, Andreas, "Quo vadis euro area? Challenges facing monetary union", available at: http://www.bundesbank.de/download/presse/reden/2011/20111020.dombret.en.pdf (2011).

Durlauf, Steven, and Marcel Fafchamps, "Social Capital", NBER Working Paper No. W10485 (2004).

Ekinci, Mehmet, Sebnem Kalemli-Özcan, and Bent Sørensen, "Financial Integration within EU Countries: The Role of Institutions, Confidence and Trust”, NBER Working Paper No. 13440 (2009).

Favero, Carlo, Marco Pagano, and Ernst-Ludwig von Thadden, "Valuation, Liquidity, and Risk in Government Bond Markets”, IGIER Working Papers No. 281 (2005).

Fischer, Justina, and Volker Hahn, "Determinants of Trust in the European Central Bank", Working Paper Series in Economics and Finance 695, Stockholm School of Economics (2008). 
Foster, Nigel, “Blackstone's EU Treaties and Legislation 2011-2012”, 22nd ed. (New York: Oxford University Press, 2011).

Georgarakos, Dimitris, and Giacomo Pasini, "Trust, Sociability and Stock Market Participation", Review of Finance 15 (2011), 693-725.

Georgarakos, Dimitris, and Sven Fürth, "Household Repayment Behavior: The Role of Social Capital, Institutional, Political, and Religious Beliefs", Working Paper (2010).

Glaeser, Edward, David Laibson, Jose Scheinkman, and Christine Soutter, "Measuring Trust", Quarterly Journal of Economics 115:3 (2000), 811-846.

Gros, Daniel, and Felix Roth, “The Financial Crisis and Citizens' Trust in the European Central Bank", CEPS Working Document No. 334 (2010).

Guiso, Luigi, Paola Sapienza, and Luigi Zingales, “The Role of Social Capital in Financial Development", American Economic Review 94 (2004), 526-556.

Knack, Stephen, and Philip Keefer, "Does Social Capital Have an Economic Payoff? A Cross-Country Investigation”, Quarterly Journal of Economics 112:4 (1997), 12511288.

La Porta, Rafael, Florencio Lopez-de-Silanes, Andrei Shleifer, and Robert W. Vishny, "Trust in Large Organizations", American Economic Review 87:2 (1997), 333-338.

Norton, Edward, Hua Wang, and Chunrong Ai, "Computing Interaction Effects and Standard Errors in Logit and Probit Models", The Stata Journal 4 (2004), 154-167.

Pagano, Marco, and Ernst-Ludwig von Thadden, "The European Bond Markets under EMU”, Oxford Review of Economic Policy 20:4 (2004), 531-554.

Rogoff, Kenneth, “The Optimal Degree of Commitment to an Intermediate Target” Quarterly Journal of Economics 100 (1985), 1169-1190.

Sturzenegger, Federico, “Toolkit for an Analysis of Debt Problems”, Working Paper (2002).

Tabellini, Guido, "Culture and Institutions: Economic Development in the Regions of Europe", Journal of the European Economic Association 8:4 (2010), 677-716.

Uslaner, Eric, "Trust and Corruption" in "Corruption and the New Institutional Economics", Johann Lambsdorf, Markus Taube, and Matthias Schramm (eds.), 1st ed. (London: Routledge, 2004).

Walsh, Carl, "Monetary Theory and Policy", 2nd ed. (Cambridge, MA: MIT Press, 2010).

Walsh, Carl, "Optimal Contracts for Central Bankers", American Economic Review 85 (1995), 150-167.

Weber, Axel, "Challenges for Monetary Policy in the European Monetary Union", Federal Reserve Bank of St. Louis Review 93:4 (2011), 235-242. 
Zak, Paul, and Stephan Knack, “Trust and Growth”, The Economic Journal 111 (1999), 295321. 
Table 1 Characteristics of Trust in the European Central Bank

The table presents the average level of trust in the European Central Bank for different time periods and countries.

\begin{tabular}{|c|c|c|c|c|c|c|c|c|c|c|c|c|c|c|}
\hline Year & Period & Austria & Belgium & Germany & Spain & Finland & France & Greece & Ireland & Italy & Luxembourg & Netherlands & Portugal & All \\
\hline \multirow[t]{2}{*}{1999} & Q1-2 & 0.62 & 0.62 & 0.66 & 0.62 & 0.70 & 0.58 & 0.59 & 0.82 & 0.78 & 0.83 & 0.84 & 0.71 & 0.69 \\
\hline & Q3-4 & 0.65 & 0.63 & 0.63 & 0.70 & 0.64 & 0.57 & 0.57 & 0.77 & 0.77 & 0.70 & 0.89 & 0.82 & 0.69 \\
\hline \multirow[t]{2}{*}{2000} & Q1-2 & 0.55 & 0.66 & 0.58 & 0.70 & 0.61 & 0.61 & 0.74 & 0.80 & 0.71 & 0.74 & 0.84 & 0.78 & 0.68 \\
\hline & Q3-4 & 0.58 & 0.62 & 0.60 & 0.65 & 0.63 & 0.56 & 0.58 & 0.79 & 0.71 & 0.75 & 0.78 & 0.72 & 0.66 \\
\hline \multirow[t]{2}{*}{2001} & Q1-2 & 0.59 & 0.65 & 0.65 & 0.62 & 0.63 & 0.60 & 0.60 & 0.83 & 0.70 & 0.78 & 0.82 & 0.74 & 0.68 \\
\hline & Q3-4 & 0.67 & 0.70 & 0.69 & 0.68 & 0.71 & 0.63 & 0.66 & 0.85 & 0.78 & 0.80 & 0.83 & 0.72 & 0.72 \\
\hline \multirow[t]{2}{*}{2002} & Q1-2 & 0.65 & 0.65 & 0.73 & 0.62 & 0.71 & 0.55 & 0.65 & 0.83 & 0.83 & 0.80 & 0.81 & 0.79 & 0.72 \\
\hline & Q3-4 & 0.72 & 0.78 & 0.74 & 0.71 & 0.69 & 0.57 & 0.64 & 0.84 & 0.80 & 0.79 & 0.77 & 0.71 & 0.73 \\
\hline \multirow[t]{2}{*}{2003} & Q1-2 & 0.64 & 0.69 & 0.73 & 0.61 & 0.77 & 0.61 & 0.70 & 0.79 & 0.76 & 0.79 & 0.79 & 0.76 & 0.72 \\
\hline & Q3-4 & 0.64 & 0.62 & 0.66 & 0.63 & 0.68 & 0.53 & 0.76 & 0.81 & 0.72 & 0.78 & 0.72 & 0.72 & 0.68 \\
\hline \multirow[t]{2}{*}{2004} & Q1-2 & 0.57 & 0.65 & 0.67 & 0.65 & 0.77 & 0.56 & 0.73 & 0.82 & 0.65 & 0.79 & 0.77 & 0.70 & 0.69 \\
\hline & Q3-4 & 0.67 & 0.77 & 0.66 & 0.66 & 0.73 & 0.59 & 0.72 & 0.80 & 0.71 & 0.78 & 0.84 & 0.79 & 0.72 \\
\hline \multirow[t]{2}{*}{2005} & Q1-2 & 0.64 & 0.75 & 0.62 & 0.55 & 0.78 & 0.51 & 0.64 & 0.74 & 0.73 & 0.83 & 0.78 & 0.79 & 0.69 \\
\hline & Q3-4 & 0.63 & 0.68 & 0.65 & 0.57 & 0.62 & 0.51 & 0.59 & 0.79 & 0.63 & 0.83 & 0.79 & 0.79 & 0.67 \\
\hline \multirow[t]{2}{*}{2006} & Q1-2 & 0.63 & 0.71 & 0.65 & 0.63 & 0.72 & 0.52 & 0.58 & 0.78 & 0.75 & 0.78 & 0.82 & 0.73 & 0.69 \\
\hline & Q3-4 & 0.64 & 0.72 & 0.69 & 0.64 & 0.67 & 0.50 & 0.62 & 0.78 & 0.56 & 0.78 & 0.84 & 0.73 & 0.68 \\
\hline \multirow[t]{2}{*}{2007} & Q1-2 & 0.62 & 0.75 & 0.73 & 0.67 & 0.74 & 0.53 & 0.55 & 0.80 & 0.69 & 0.76 & 0.85 & 0.70 & 0.70 \\
\hline & Q3-4 & 0.66 & 0.71 & 0.74 & 0.63 & 0.74 & 0.59 & 0.53 & 0.77 & 0.61 & 0.77 & 0.88 & 0.67 & 0.69 \\
\hline \multirow[t]{2}{*}{2008} & Q1-2 & 0.63 & 0.72 & 0.69 & 0.78 & 0.78 & 0.56 & 0.50 & 0.83 & 0.64 & 0.77 & 0.89 & 0.74 & 0.71 \\
\hline & Q3-4 & 0.65 & 0.67 & 0.63 & 0.67 & 0.79 & 0.54 & 0.52 & 0.69 & 0.59 & 0.73 & 0.88 & 0.67 & 0.66 \\
\hline \multirow[t]{3}{*}{2009} & Q1 & 0.58 & 0.53 & 0.49 & 0.55 & 0.78 & 0.36 & 0.44 & 0.60 & 0.47 & 0.57 & 0.74 & 0.51 & 0.55 \\
\hline & Q2 & 0.65 & 0.63 & 0.60 & 0.53 & 0.77 & 0.50 & 0.42 & 0.64 & 0.60 & 0.77 & 0.76 & 0.64 & 0.62 \\
\hline & Q3-4 & 0.66 & 0.62 & 0.59 & 0.58 & 0.80 & 0.46 & 0.53 & 0.66 & 0.61 & 0.77 & 0.74 & 0.69 & 0.63 \\
\hline \multirow[t]{2}{*}{2010} & Q1-2 & 0.58 & 0.58 & 0.48 & 0.52 & 0.71 & 0.42 & 0.39 & 0.54 & 0.56 & 0.70 & 0.64 & 0.53 & 0.54 \\
\hline & Q3-4 & 0.53 & 0.64 & 0.55 & 0.47 & 0.66 & 0.47 & 0.31 & 0.59 & 0.58 & 0.74 & 0.72 & 0.57 & 0.56 \\
\hline Total & & 0.63 & 0.67 & 0.64 & 0.62 & 0.72 & 0.54 & 0.57 & 0.75 & 0.67 & 0.77 & 0.80 & 0.70 & 0.67 \\
\hline
\end{tabular}


Table 2 Summary Statistics

Full Sample

Non-Crisis Period

\begin{tabular}{|c|c|c|c|c|c|c|c|c|c|c|c|c|c|c|c|}
\hline \multirow[b]{2}{*}{ Variables } & \multicolumn{5}{|c|}{ Fuir sampie } & \multicolumn{5}{|c|}{ Non-crisis Feriod } & \multicolumn{5}{|c|}{ Crisis feriod } \\
\hline & Obs. & Mean & $\mathrm{SD}$ & Min & Max & Obs. & Mean & SD & Min & Max & Obs. & Mean & SD & Min & Max \\
\hline Trust in the ECB & 188,037 & 0.686 & 0.464 & 0.000 & 1.000 & 155,649 & 0.691 & 0.462 & 0.000 & 1.000 & 32,388 & 0.660 & 0.474 & 0.000 & 1.000 \\
\hline Age & 188,037 & 48.335 & 16.519 & 20.000 & 99.000 & 155,649 & 47.965 & 16.476 & 20.000 & 99.000 & 32,388 & 50.113 & 16.614 & 20.000 & 98.000 \\
\hline Male & 188,037 & 0.505 & 0.500 & 0.000 & 1.000 & 155,649 & 0.507 & 0.500 & 0.000 & 1.000 & 32,388 & 0.496 & 0.500 & 0.000 & 1.000 \\
\hline Couple & 188,037 & 0.667 & 0.471 & 0.000 & 1.000 & 155,649 & 0.665 & 0.472 & 0.000 & 1.000 & 32,388 & 0.673 & 0.469 & 0.000 & 1.000 \\
\hline Single & 188,037 & 0.171 & 0.376 & 0.000 & 1.000 & 155,649 & 0.174 & 0.379 & 0.000 & 1.000 & 32,388 & 0.157 & 0.363 & 0.000 & 1.000 \\
\hline Divorced & 188,037 & 0.083 & 0.275 & 0.000 & 1.000 & 155,649 & 0.082 & 0.274 & 0.000 & 1.000 & 32,388 & 0.086 & 0.281 & 0.000 & 1.000 \\
\hline Self Employed & 188,037 & 0.097 & 0.295 & 0.000 & 1.000 & 155,649 & 0.098 & 0.297 & 0.000 & 1.000 & 32,388 & 0.091 & 0.287 & 0.000 & 1.000 \\
\hline Retired & 188,037 & 0.252 & 0.434 & 0.000 & 1.000 & 155,649 & 0.246 & 0.431 & 0.000 & 1.000 & 32,388 & 0.281 & 0.450 & 0.000 & 1.000 \\
\hline Unemployed & 188,037 & 0.199 & 0.399 & 0.000 & 1.000 & 155,649 & 0.202 & 0.402 & 0.000 & 1.000 & 32,388 & 0.180 & 0.384 & 0.000 & 1.000 \\
\hline High School Degree & 188,037 & 0.184 & 0.388 & 0.000 & 1.000 & 155,649 & 0.185 & 0.389 & 0.000 & 1.000 & 32,388 & 0.179 & 0.383 & 0.000 & 1.000 \\
\hline College Degree & 188,037 & 0.570 & 0.495 & 0.000 & 1.000 & 155,649 & 0.568 & 0.495 & 0.000 & 1.000 & 32,388 & 0.582 & 0.493 & 0.000 & 1.000 \\
\hline Political Position & 188,037 & 5.205 & 2.016 & 1.000 & 10.000 & 155,649 & 5.207 & 2.003 & 1.000 & 10.000 & 32,388 & 5.195 & 2.077 & 1.000 & 10.000 \\
\hline GDP Growth & 188,037 & 0.912 & 1.665 & -6.037 & 7.764 & 155,649 & 1.272 & 1.311 & -3.147 & 7.764 & 32,388 & -0.817 & 2.054 & -6.037 & 2.868 \\
\hline Inflation Deviation & 188,037 & 0.975 & 0.850 & 0.000 & 4.800 & 155,649 & 0.980 & 0.874 & 0.000 & 4.800 & 32,388 & 0.951 & 0.723 & 0.000 & 2.567 \\
\hline Government Debt & 172,409 & 66.071 & 27.041 & 5.500 & 132.450 & 140,021 & 66.442 & 27.227 & 5.500 & 132.450 & 32,388 & 64.469 & 26.158 & 6.700 & 118.700 \\
\hline Government Bond Spread & 179,796 & 0.194 & 0.769 & -0.763 & 9.215 & 148,591 & 0.177 & 0.826 & -0.763 & 9.215 & 31,205 & 0.271 & 0.389 & -0.137 & 1.736 \\
\hline Unemployment Rate & 188,037 & 6.629 & 2.718 & 1.400 & 18.050 & 155,649 & 6.756 & 2.769 & 1.400 & 18.050 & 32,388 & 6.018 & 2.360 & 2.000 & 15.500 \\
\hline Regional GDP Growth & 140,629 & 4.988 & 2.970 & -4.248 & 23.849 & 124,889 & 4.866 & 3.075 & -4.248 & 23.849 & 15,740 & 5.958 & 1.653 & 2.438 & 10.321 \\
\hline Regional Unemployment Rate & 159,205 & 6.978 & 4.128 & 1.600 & 23.000 & 130,825 & 7.167 & 4.273 & 1.600 & 23.000 & 28,380 & 6.107 & 3.241 & 2.200 & 17.100 \\
\hline
\end{tabular}


Table $3 \quad$ Variable Description

Variable

Trust in the ECB A dummy variable indicating whether or not the respondent tends to trust the European Central

Eurobarometer Bank.

Age

The age of the respondent in years.

Eurobarometer

Male

A dummy variable indicating whether the respondent is male or female.

Eurobarometer

Couple

A dummy variable indicating that the respondent is married, remarried, or currently living with

Eurobarometer partner.

Single

A dummy variable indicating that the respondent has never or previously lived with a partner.

Eurobarometer

Divorced

A dummy variable indicating that the respondent is currently divorced or separated.

Eurobarometer

Self Employed

A dummy variable indicating that the respondent is currently self-employed.

Eurobarometer

Retired

A dummy variable indicating that the respondent is currently retired or unable to work due to

Eurobarometer illness.

Unemployed

A dummy variable indicating that the respondent is temporarily not working, a student, or responsible for ordinary shopping only.

High School

Degree

A dummy indicating that the respondent was between 15 and 17 years old when full time education was completed. If the respondent was still in full time education at the time the survey was conducted, the education level corresponding to the respondent's current age was assumed.

College Degree

A dummy variable indicating that the respondent was more than 17 years old when full time education was completed. If the respondent was still in full time education at the time the survey was conducted, the education level corresponding to the respondent's current age was assumed.

Political Position

A scale ranging from 1 up to 10 in which the respondents place themselves and where 1 represents left-wing and 10 right-wing political views.

GDP Growth

Compounded national quarter-to-quarter growth rates of seasonally adjusted chain-linked quarterly real gross domestic product.

Inflation Deviation The absolute difference between the average annual change in the Harmonized Index of Consumer Prices and the European Central Bank's implicit inflation target of 2 percent.

Government Debt The absolute national level of government debt relative to national gross domestic product.

Eurostat

Government Bond The government bond yield spread over German bonds in the respective period using data on one Spread year government bonds with constant maturity.

Thomson Reuters Datastream

Unemployment

The average national unemployment rate.

Eurostat

Rate

Regional GDP

Growth

The average regional gross domestic product growth rate identified using the Nomenclature of

Eurostat Territorial Units for Statistics of the European Union.

Regional

Unemployment

The average regional unemployment rate identified using the Nomenclature of Territorial Units for Statistics of the European Union.

Eurostat

Rate 


\section{Table 4 Cross Sectional Probit Regressions - Socio-Economic Characteristics}

The table presents marginal effects from multivariate probit regressions using the delta method. Values of the z-statistics are in parentheses. Standard errors were corrected for heteroscedasticity. $* * *, * * *$ denote significance at $1 \%, 5 \%$, and $10 \%$, respectively. The specifications account for age and political position through second-order polynomials.

\begin{tabular}{|c|c|c|c|c|}
\hline \multirow{2}{*}{ Variables } & \multicolumn{4}{|c|}{$\begin{array}{l}\text { Dependent: Trust in the European Central Bank } \\
\begin{array}{ll}(1) & (2)\end{array}\end{array}$} \\
\hline & $\begin{array}{c}\text { Marginal } \\
\text { Effects }\end{array}$ & & $\begin{array}{l}\text { Marginal } \\
\text { Effects }\end{array}$ & \\
\hline Age & $\begin{array}{c}0.001 \\
(12.468)\end{array}$ & $* * *$ & $\begin{array}{c}0.001 \\
(9.813)\end{array}$ & $* * *$ \\
\hline Male & $\begin{array}{c}0.029 \\
(12.965)\end{array}$ & $* * *$ & $\begin{array}{c}0.028 \\
(12.577)\end{array}$ & $* * *$ \\
\hline Couple & $\begin{array}{c}0.038 \\
(8.481)\end{array}$ & $* * *$ & $\begin{array}{c}0.035 \\
(7.782)\end{array}$ & $* * *$ \\
\hline Single & $\begin{array}{c}0.021 \\
(3.895)\end{array}$ & $* * *$ & $\begin{array}{c}0.015 \\
(2.860)\end{array}$ & $* * *$ \\
\hline Divorced & $\begin{array}{c}-0.022 \\
(-3.738)\end{array}$ & $* * *$ & $\begin{array}{c}-0.016 \\
(-2.860)\end{array}$ & $* * *$ \\
\hline Self Employed & $\begin{array}{c}-0.010 \\
(-2.715)\end{array}$ & $* * *$ & $\begin{array}{c}-0.002 \\
(-0.530)\end{array}$ & \\
\hline Retired & $\begin{array}{c}-0.026 \\
(-6.728)\end{array}$ & $* * *$ & $\begin{array}{c}-0.015 \\
(-3.922)\end{array}$ & $* * *$ \\
\hline Unemployed & $\begin{array}{c}-0.031 \\
(-10.294)\end{array}$ & $* * *$ & $\begin{array}{c}-0.031 \\
(-10.536)\end{array}$ & $* * *$ \\
\hline High School Degree & $\begin{array}{c}0.037 \\
(10.516)\end{array}$ & $* * *$ & $\begin{array}{c}0.035 \\
(9.701)\end{array}$ & $* * *$ \\
\hline College Degree & $\begin{array}{c}0.111 \\
(39.046)\end{array}$ & $* * *$ & $\begin{array}{c}0.113 \\
(38.043)\end{array}$ & $* * *$ \\
\hline $\begin{array}{l}\text { Political Position } \\
\text { (Right to Left) }\end{array}$ & $\begin{array}{c}-0.014 \\
(-25.833)\end{array}$ & $* * *$ & $\begin{array}{c}-0.013 \\
(-23.405)\end{array}$ & $* * *$ \\
\hline Country Fixed Effects & No & & Yes & \\
\hline Observations & 188,037 & & 188,037 & \\
\hline
\end{tabular}


Table 5 Cross Sectional Probit Regressions - Macroeconomic Condition

The table presents marginal effects from multivariate probit regressions using the delta method. Values of the z-statistics are in parentheses. Standard errors were corrected for heteroscedasticity. $* * *, * * *$ denote significance at $1 \%, 5 \%$, and $10 \%$, respectively. The specifications account for age and political position through second-order polynomials.

\begin{tabular}{|c|c|c|c|c|c|c|c|c|c|c|c|c|}
\hline \multirow{3}{*}{ Variables } & \multicolumn{12}{|c|}{ Dependent: Trust in the European Central Bank } \\
\hline & (1) & & (2) & & (3) & & (4) & & (5) & & (6) & \\
\hline & $\begin{array}{c}\text { Marginal } \\
\text { Effects }\end{array}$ & & $\begin{array}{c}\text { Marginal } \\
\text { Effects }\end{array}$ & & $\begin{array}{c}\text { Marginal } \\
\text { Effects }\end{array}$ & & $\begin{array}{c}\text { Marginal } \\
\text { Effects }\end{array}$ & & $\begin{array}{c}\text { Marginal } \\
\text { Effects }\end{array}$ & & $\begin{array}{c}\text { Marginal } \\
\text { Effects }\end{array}$ & \\
\hline GDP Growth & $\begin{array}{c}0.016 \\
(25.383)\end{array}$ & **** & & & & & & & & & $\begin{array}{c}0.010 \\
(13.583)\end{array}$ & **** \\
\hline Inflation Deviation & & & $\begin{array}{c}-0.008 \\
(-6.727)\end{array}$ & $* * *$ & & & & & & & $\begin{array}{c}0.002 \\
(1.201)\end{array}$ & \\
\hline Government Debt & & & & & $\begin{array}{c}-0.002 \\
(-37.322)\end{array}$ & $* * *$ & & & & & $\begin{array}{c}-0.001 \\
(-22.856)\end{array}$ & $* * *$ \\
\hline $\begin{array}{l}\text { Government Bond } \\
\text { Spread }\end{array}$ & & & & & & & -0.029 & $* * *$ & & & -0.030 & $* * *$ \\
\hline & & & & & & & $(-21.068)$ & & & & $(-12.562)$ & \\
\hline Unemployment Rate & & & & & & & & & $\begin{array}{c}-0.015 \\
(-38.892)\end{array}$ & $* * *$ & $\begin{array}{c}-0.012 \\
(-26.703)\end{array}$ & $* * *$ \\
\hline Age & $\begin{array}{c}0.001 \\
(12.956)\end{array}$ & **** & $\begin{array}{c}0.001 \\
(12.506)\end{array}$ & $* * *$ & $\begin{array}{c}0.001 \\
(11.276)\end{array}$ & $* * *$ & $\begin{array}{c}0.001 \\
(11.408)\end{array}$ & $* * *$ & $\begin{array}{c}0.001 \\
(11.256)\end{array}$ & **** & $\begin{array}{c}0.001 \\
(10.336)\end{array}$ & **** \\
\hline Male & $\begin{array}{c}0.029 \\
(12.787)\end{array}$ & $* * *$ & $\begin{array}{c}0.029 \\
(13.006)\end{array}$ & $* * *$ & $\begin{array}{c}0.029 \\
(12.647)\end{array}$ & $* * *$ & $\begin{array}{c}0.031 \\
(13.437)\end{array}$ & $* * *$ & $\begin{array}{c}0.030 \\
(13.246)\end{array}$ & $* * *$ & $\begin{array}{c}0.032 \\
(13.531)\end{array}$ & $* * *$ \\
\hline Couple & $\begin{array}{c}0.039 \\
(8.708)\end{array}$ & $* * *$ & $\begin{array}{c}0.039 \\
(8.545)\end{array}$ & $* * *$ & $\begin{array}{c}0.037 \\
(7.918)\end{array}$ & $* * *$ & $\begin{array}{c}0.038 \\
(8.221)\end{array}$ & $* * *$ & $\begin{array}{c}0.038 \\
(8.406)\end{array}$ & $* * *$ & $\begin{array}{c}0.037 \\
(7.743)\end{array}$ & $* * *$ \\
\hline Single & $\begin{array}{c}0.022 \\
(4.156)\end{array}$ & $* * *$ & $\begin{array}{c}0.021 \\
(3.960)\end{array}$ & $* * *$ & $\begin{array}{c}0.022 \\
(3.959)\end{array}$ & $* * *$ & $\begin{array}{c}0.022 \\
(4.015)\end{array}$ & $* * *$ & $\begin{array}{c}0.022 \\
(4.181)\end{array}$ & $* * *$ & $\begin{array}{c}0.023 \\
(3.981)\end{array}$ & $* * *$ \\
\hline Divorced & $\begin{array}{c}-0.020 \\
(-3.470)\end{array}$ & $* * *$ & $\begin{array}{c}-0.022 \\
(-3.825)\end{array}$ & $* * *$ & $\begin{array}{c}-0.023 \\
(-3.895)\end{array}$ & $* * *$ & $\begin{array}{c}-0.022 \\
(-3.760)\end{array}$ & $* * *$ & $\begin{array}{c}-0.022 \\
(-3.731)\end{array}$ & $* * *$ & $\begin{array}{c}-0.022 \\
(-3.533)\end{array}$ & $* * *$ \\
\hline Self Employed & $\begin{array}{c}-0.011 \\
(-2.822)\end{array}$ & $* * *$ & $\begin{array}{c}-0.010 \\
(-2.601)\end{array}$ & $* * *$ & $\begin{array}{c}0.006 \\
(1.540)\end{array}$ & & $\begin{array}{c}-0.003 \\
(-0.652)\end{array}$ & & $\begin{array}{c}-0.006 \\
(-1.574)\end{array}$ & & $\begin{array}{c}0.007 \\
(1.763)\end{array}$ & * \\
\hline Retired & $\begin{array}{c}-0.025 \\
(-6.599)\end{array}$ & $* * *$ & $\begin{array}{c}-0.026 \\
(-6.839)\end{array}$ & $* * *$ & $\begin{array}{c}-0.018 \\
(-4.510)\end{array}$ & $* * *$ & $\begin{array}{c}-0.026 \\
(-6.631)\end{array}$ & $* * *$ & $\begin{array}{c}-0.022 \\
(-5.799)\end{array}$ & $* * *$ & $\begin{array}{c}-0.017 \\
(-4.279)\end{array}$ & $* * *$ \\
\hline Unemployed & $\begin{array}{c}-0.031 \\
(-10.303)\end{array}$ & $* * *$ & $\begin{array}{c}-0.030 \\
(-10.082)\end{array}$ & $* * *$ & $\begin{array}{c}-0.029 \\
(-9.148)\end{array}$ & $* * *$ & $\begin{array}{c}-0.030 \\
(-9.941)\end{array}$ & $* * *$ & $\begin{array}{c}-0.026 \\
(-8.896)\end{array}$ & $* * *$ & $\begin{array}{c}-0.026 \\
(-8.094)\end{array}$ & $* * *$ \\
\hline High School Degree & $\begin{array}{c}0.037 \\
(10.553)\end{array}$ & $* * *$ & $\begin{array}{c}0.036 \\
(10.406)\end{array}$ & $* * *$ & $\begin{array}{c}0.028 \\
(7.518)\end{array}$ & $* * *$ & $\begin{array}{c}0.033 \\
(9.143)\end{array}$ & $* * *$ & $\begin{array}{c}0.032 \\
(9.158)\end{array}$ & $* * *$ & $\begin{array}{c}0.026 \\
(6.834)\end{array}$ & $* * *$ \\
\hline College Degree & $\begin{array}{c}0.112 \\
(39.382)\end{array}$ & $* * *$ & $\begin{array}{c}0.111 \\
(38.848)\end{array}$ & $* * *$ & $\begin{array}{c}0.116 \\
(38.650)\end{array}$ & $* * *$ & $\begin{array}{c}0.111 \\
(38.083)\end{array}$ & $* * *$ & $\begin{array}{c}0.103 \\
(36.087)\end{array}$ & $* * *$ & $\begin{array}{c}0.112 \\
(36.507)\end{array}$ & $* * *$ \\
\hline $\begin{array}{l}\text { Political Position } \\
\text { (Right to Left) }\end{array}$ & $\begin{array}{c}-0.014 \\
(-25.444) \\
\end{array}$ & $* * *$ & $\begin{array}{c}-0.014 \\
(-25.869) \\
\end{array}$ & $* * *$ & $\begin{array}{c}-0.014 \\
(-24.797) \\
\end{array}$ & $* * *$ & $\begin{array}{c}-0.014 \\
(-25.580) \\
\end{array}$ & $* * *$ & $\begin{array}{c}-0.013 \\
(-24.048) \\
\end{array}$ & $* * *$ & $\begin{array}{c}-0.013 \\
(-22.715) \\
\end{array}$ & $* * *$ \\
\hline Observations & 188,037 & & 188,037 & & 172,409 & & 179,796 & & 188,037 & & 165,112 & \\
\hline
\end{tabular}




\section{Table 6 Cross Sectional Probit Regressions - Macroeconomic Condition and the Crisis Period}

The table presents marginal effects from multivariate probit regressions using the delta method. Values of the z-statistics are in parentheses. Standard errors were corrected for heteroscedasticity. $* * * * * *$ denote significance at $1 \%, 5 \%$, and $10 \%$, respectively. The specifications account for age and political position through second-order polynomials.

\begin{tabular}{|c|c|c|c|c|c|c|c|c|c|c|c|c|}
\hline \multirow{3}{*}{ Variables } & \multicolumn{12}{|c|}{ Dependent: Trust in the European Central Bank } \\
\hline & (1) & & (2) & & (3) & & (4) & & (5) & & (6) & \\
\hline & $\begin{array}{c}\text { Marginal } \\
\text { Effects }\end{array}$ & & $\begin{array}{c}\text { Marginal } \\
\text { Effects }\end{array}$ & & $\begin{array}{c}\text { Marginal } \\
\text { Effects }\end{array}$ & & $\begin{array}{c}\text { Marginal } \\
\text { Effects }\end{array}$ & & $\begin{array}{c}\text { Marginal } \\
\text { Effects }\end{array}$ & & $\begin{array}{c}\text { Marginal } \\
\text { Effects }\end{array}$ & \\
\hline GDP Growth & $\begin{array}{c}0.016 \\
(22.567)\end{array}$ & **** & & & & & & & & & $\begin{array}{c}0.008 \\
(8.829)\end{array}$ & $* * *$ \\
\hline Inflation Deviation & & & $\begin{array}{c}-0.009 \\
(-6.851)\end{array}$ & $* * *$ & & & & & & & $\begin{array}{c}0.001 \\
(0.937)\end{array}$ & \\
\hline Government Debt & & & & & $\begin{array}{c}-0.002 \\
(-37.619)\end{array}$ & $* * *$ & & & & & $\begin{array}{c}-0.001 \\
(-23.199)\end{array}$ & $* * *$ \\
\hline Government Bond Spread & & & & & & & $\begin{array}{c}-0.029 \\
(-20.691)\end{array}$ & $* * *$ & & & $\begin{array}{c}-0.030 \\
(-12.517)\end{array}$ & $* * *$ \\
\hline Unemployment Rate & & & & & & & & & $\begin{array}{c}-0.015 \\
(-40.260)\end{array}$ & $* * *$ & $\begin{array}{c}-0.012 \\
(-27.271)\end{array}$ & $* * *$ \\
\hline Crisis Period & $\begin{array}{c}0.002 \\
(0.533)\end{array}$ & & $\begin{array}{c}-0.033 \\
(-11.553)\end{array}$ & $* * *$ & $\begin{array}{c}-0.033 \\
(-11.572)\end{array}$ & $* * *$ & $\begin{array}{c}-0.028 \\
(-9.500)\end{array}$ & $* * *$ & $\begin{array}{c}-0.044 \\
(-15.401)\end{array}$ & $* * *$ & $\begin{array}{c}-0.020 \\
(-6.005)\end{array}$ & $* * *$ \\
\hline Age & $\begin{array}{c}0.001 \\
(12.921)\end{array}$ & $* * *$ & $\begin{array}{c}0.001 \\
(12.996)\end{array}$ & $* * *$ & $\begin{array}{c}0.001 \\
(11.716)\end{array}$ & $* * *$ & $\begin{array}{c}0.001 \\
(11.826)\end{array}$ & $* * *$ & $\begin{array}{c}0.001 \\
(11.863)\end{array}$ & $* * *$ & $\begin{array}{c}0.001 \\
(10.516)\end{array}$ & $* * *$ \\
\hline Male & $\begin{array}{c}0.029 \\
(12.793)\end{array}$ & $* * *$ & $\begin{array}{c}0.029 \\
(12.823)\end{array}$ & $* * *$ & $\begin{array}{c}0.029 \\
(12.473)\end{array}$ & $* * *$ & $\begin{array}{c}0.031 \\
(13.289)\end{array}$ & $* * *$ & $\begin{array}{c}0.029 \\
(13.011)\end{array}$ & $* * *$ & $\begin{array}{c}0.032 \\
(13.452)\end{array}$ & $* * *$ \\
\hline Couple & $\begin{array}{c}0.039 \\
(8.702)\end{array}$ & $* * *$ & $\begin{array}{c}0.039 \\
(8.697)\end{array}$ & $* * *$ & $\begin{array}{c}0.038 \\
(8.050)\end{array}$ & $* * *$ & $\begin{array}{c}0.039 \\
(8.349)\end{array}$ & $* * *$ & $\begin{array}{c}0.039 \\
(8.607)\end{array}$ & $* * *$ & $\begin{array}{c}0.038 \\
(7.804)\end{array}$ & $* * *$ \\
\hline Single & $\begin{array}{c}0.022 \\
(4.153)\end{array}$ & $* * *$ & $\begin{array}{c}0.022 \\
(4.087)\end{array}$ & $* * *$ & $\begin{array}{c}0.023 \\
(4.061)\end{array}$ & $* * *$ & $\begin{array}{c}0.023 \\
(4.112)\end{array}$ & $* * *$ & $\begin{array}{c}0.023 \\
(4.362)\end{array}$ & $* * *$ & $\begin{array}{c}0.023 \\
(4.024)\end{array}$ & $* * *$ \\
\hline Divorced & $\begin{array}{c}-0.020 \\
(-3.473)\end{array}$ & $* * *$ & $\begin{array}{c}-0.021 \\
(-3.696)\end{array}$ & $* * *$ & $\begin{array}{c}-0.023 \\
(-3.792)\end{array}$ & $* * *$ & $\begin{array}{c}-0.022 \\
(-3.651)\end{array}$ & $* * *$ & $\begin{array}{c}-0.021 \\
(-3.558)\end{array}$ & $* * *$ & $\begin{array}{c}-0.021 \\
(-3.497)\end{array}$ & $* * *$ \\
\hline Self Employed & $\begin{array}{l}-0.011 \\
(-2.817)\end{array}$ & $* * *$ & $\begin{array}{c}-0.010 \\
(-2.708)\end{array}$ & $* * *$ & $\begin{array}{l}0.006 \\
(1.471)\end{array}$ & & $\begin{array}{c}-0.003 \\
(-0.768)\end{array}$ & & $\begin{array}{c}-0.006 \\
(-1.675)\end{array}$ & $*$ & $\begin{array}{c}0.007 \\
(1.785)\end{array}$ & $*$ \\
\hline Retired & $\begin{array}{c}-0.025 \\
(-6.591)\end{array}$ & *** & $\begin{array}{c}-0.027 \\
(-6.937)\end{array}$ & $* * *$ & $\begin{array}{c}-0.018 \\
(-4.598)\end{array}$ & $* * *$ & $\begin{array}{c}-0.026 \\
(-6.715)\end{array}$ & $* * *$ & $\begin{array}{c}-0.023 \\
(-5.897)\end{array}$ & $* * *$ & $\begin{array}{c}-0.018 \\
(-4.317)\end{array}$ & $* * *$ \\
\hline Unemployed & $\begin{array}{c}-0.031 \\
(-10.292)\end{array}$ & $* * *$ & $\begin{array}{c}-0.031 \\
(-10.264)\end{array}$ & $* * *$ & $\begin{array}{c}-0.029 \\
(-9.331)\end{array}$ & $* * *$ & $\begin{array}{c}-0.031 \\
(-10.101)\end{array}$ & $* * *$ & $\begin{array}{c}-0.027 \\
(-9.081)\end{array}$ & $* * *$ & $\begin{array}{c}-0.026 \\
(-8.152)\end{array}$ & $* * *$ \\
\hline High School Degree & $\begin{array}{c}0.037 \\
(10.546)\end{array}$ & $* * *$ & $\begin{array}{c}0.037 \\
(10.520)\end{array}$ & $* * *$ & $\begin{array}{c}0.028 \\
(7.598)\end{array}$ & $* * *$ & $\begin{array}{c}0.033 \\
(9.263)\end{array}$ & $* * *$ & $\begin{array}{c}0.032 \\
(9.249)\end{array}$ & $* * *$ & $\begin{array}{c}0.026 \\
(6.811)\end{array}$ & $* * *$ \\
\hline College Degree & $\begin{array}{c}0.112 \\
(39.354)\end{array}$ & $* * *$ & $\begin{array}{c}0.112 \\
(39.121)\end{array}$ & $* * *$ & $\begin{array}{c}0.116 \\
(38.866)\end{array}$ & $* * *$ & $\begin{array}{c}0.112 \\
(38.326)\end{array}$ & $* * *$ & $\begin{array}{c}0.104 \\
(36.328)\end{array}$ & $* * *$ & $\begin{array}{c}0.112 \\
(36.535)\end{array}$ & $* * *$ \\
\hline $\begin{array}{l}\text { Political Position } \\
\text { (Right to Left) }\end{array}$ & $\begin{array}{c}-0.014 \\
(-25.445) \\
\end{array}$ & $* * *$ & $\begin{array}{c}-0.014 \\
(-25.763) \\
\end{array}$ & $* * *$ & $\begin{array}{c}-0.014 \\
(-24.714) \\
\end{array}$ & $* * *$ & $\begin{array}{c}-0.014 \\
(-25.472) \\
\end{array}$ & $* * *$ & $\begin{array}{c}-0.013 \\
(-23.824) \\
\end{array}$ & $* * *$ & $\begin{array}{c}-0.013 \\
(-22.650) \\
\end{array}$ & $* * *$ \\
\hline Observations & 188,037 & & 188,037 & & 172,409 & & 179,796 & & 188,037 & & 165,112 & \\
\hline
\end{tabular}


Table 7 Cross Sectional Probit Regressions - Interaction Effects

The table presents marginal effects from multivariate probit regressions using the delta method. The interaction effects were calculated using the methodology provided by Norton et al. (2004). Values of the z-statistics are in parentheses. Standard errors were corrected for heteroscedasticity. $* * *, * *, *$ denote significance at $1 \%, 5 \%$, and $10 \%$, respectively. The specifications account for age and political position through second-order polynomials.

\begin{tabular}{|c|c|c|c|c|c|c|c|c|c|c|}
\hline \multirow{3}{*}{ Variables } & \multicolumn{10}{|c|}{ Dependent: Trust in the European Central Bank } \\
\hline & $(1)$ & & (2) & 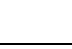 & (3) & ( & (4) & & $(5)$ & \\
\hline & $\begin{array}{c}\text { Marginal } \\
\text { Effects }\end{array}$ & & $\begin{array}{c}\text { Marginal } \\
\text { Effects }\end{array}$ & & $\begin{array}{c}\text { Marginal } \\
\text { Effects }\end{array}$ & & $\begin{array}{c}\text { Marginal } \\
\text { Effects }\end{array}$ & & $\begin{array}{c}\text { Marginal } \\
\text { Effects }\end{array}$ & \\
\hline $\begin{array}{l}\text { GDP Growth } x \\
\text { Crisis Period }\end{array}$ & $\begin{array}{c}0.011 \\
(-6.511)\end{array}$ & $* * *$ & & & & & & & & \\
\hline $\begin{array}{l}\text { Inflation Deviation x } \\
\text { Crisis Period }\end{array}$ & & & $\begin{array}{c}-0.007 \\
(-1.696)\end{array}$ & & & & & & & \\
\hline $\begin{array}{l}\text { Government Debt x } \\
\text { Crisis Period }\end{array}$ & & & & & $\begin{array}{c}-0.002 \\
(-13.252)\end{array}$ & $* * *$ & & & & \\
\hline $\begin{array}{l}\text { Government Bond Spread x } \\
\text { Crisis Period }\end{array}$ & & & & & & & $\begin{array}{c}-0.058 \\
(-8.563)\end{array}$ & $* * *$ & & \\
\hline $\begin{array}{l}\text { Unemployment Rate } \mathrm{x} \\
\text { Crisis Period }\end{array}$ & & & & & & & & & $\begin{array}{l}-0.004 \\
(-3.434)\end{array}$ & $* * *$ \\
\hline GDP Growth & $\begin{array}{c}0.005 \\
(5.361)\end{array}$ & $* * *$ & $\begin{array}{c}0.008 \\
(8.920)\end{array}$ & $* * *$ & $\begin{array}{c}0.009 \\
(9.904)\end{array}$ & $* * *$ & $\begin{array}{c}0.007 \\
(7.962)\end{array}$ & $* * *$ & $\begin{array}{c}0.007 \\
(8.625)\end{array}$ & $* * *$ \\
\hline Inflation Deviation & $\begin{array}{c}0.001 \\
(0.443)\end{array}$ & & $\begin{array}{c}0.001 \\
(0.652)\end{array}$ & & $\begin{array}{c}0.002 \\
(1.260)\end{array}$ & & $\begin{array}{c}0.001 \\
(0.411)\end{array}$ & & $\begin{array}{c}0.001 \\
(1.029)\end{array}$ & \\
\hline Government Debt & $\begin{array}{c}-0.001 \\
(-23.741)\end{array}$ & $* * *$ & $\begin{array}{c}-0.001 \\
(-23.109)\end{array}$ & $* * *$ & $\begin{array}{c}-0.001 \\
(-23.313)\end{array}$ & $* * *$ & $\begin{array}{c}-0.001 \\
(-22.337)\end{array}$ & $* * *$ & $\begin{array}{c}-0.001 \\
(-23.246)\end{array}$ & $* * *$ \\
\hline Government Bond Spread & $\begin{array}{c}-0.031 \\
(-12.882)\end{array}$ & $* * *$ & $\begin{array}{c}-0.030 \\
(-12.607)\end{array}$ & $* * *$ & $\begin{array}{c}-0.029 \\
(-12.025)\end{array}$ & $* * *$ & $\begin{array}{c}-0.035 \\
(-14.367)\end{array}$ & $* * *$ & $\begin{array}{l}-0.030 \\
(-12.703)\end{array}$ & $* * *$ \\
\hline Unemployment Rate & $\begin{array}{c}-0.012 \\
(-27.280)\end{array}$ & $* * *$ & $\begin{array}{c}-0.012 \\
(-27.159)\end{array}$ & $* * *$ & $\begin{array}{c}-0.012 \\
(-27.723)\end{array}$ & $* * *$ & $\begin{array}{c}-0.012 \\
(-27.801)\end{array}$ & $* * *$ & $\begin{array}{c}-0.012 \\
(-27.460)\end{array}$ & $* * *$ \\
\hline Crisis Period & $\begin{array}{c}-0.012 \\
(-3.384)\end{array}$ & $* * *$ & $\begin{array}{c}-0.020 \\
(-6.004)\end{array}$ & $* * *$ & $\begin{array}{l}-0.021 \\
(-6.337)\end{array}$ & $* * *$ & $\begin{array}{l}-0.015 \\
(-4.327)\end{array}$ & $* * *$ & $\begin{array}{c}-0.023 \\
(-6.503)\end{array}$ & $* * *$ \\
\hline Age & $\begin{array}{c}0.001 \\
(10.613)\end{array}$ & $* * *$ & $\begin{array}{c}0.001 \\
(10.495)\end{array}$ & $* * *$ & $\begin{array}{c}0.001 \\
(10.366)\end{array}$ & $* * *$ & $\begin{array}{c}0.001 \\
(10.519)\end{array}$ & $* * *$ & $\begin{array}{c}0.001 \\
(10.465)\end{array}$ & $* * *$ \\
\hline Male & $\begin{array}{c}0.032 \\
(13.429)\end{array}$ & $* * *$ & $\begin{array}{c}0.032 \\
(13.451)\end{array}$ & $* * *$ & $\begin{array}{c}0.032 \\
(13.405)\end{array}$ & $* * *$ & $\begin{array}{c}0.032 \\
(13.476)\end{array}$ & $* * *$ & $\begin{array}{c}0.032 \\
(13.459)\end{array}$ & $* * *$ \\
\hline Couple & $\begin{array}{c}0.038 \\
(7.858)\end{array}$ & $* * *$ & $\begin{array}{c}0.038 \\
(7.799)\end{array}$ & $* * *$ & $\begin{array}{c}0.037 \\
(7.687)\end{array}$ & $* * *$ & $\begin{array}{c}0.037 \\
(7.760)\end{array}$ & $* * *$ & $\begin{array}{c}0.037 \\
(7.785)\end{array}$ & $* * *$ \\
\hline Single & $\begin{array}{c}0.023 \\
(4.070)\end{array}$ & $* * *$ & $\begin{array}{c}0.023 \\
(4.006)\end{array}$ & $* * *$ & $\begin{array}{c}0.023 \\
(4.017)\end{array}$ & $* * *$ & $\begin{array}{c}0.023 \\
(4.066)\end{array}$ & $* * *$ & $\begin{array}{c}0.023 \\
(3.999)\end{array}$ & $* * *$ \\
\hline Divorced & $\begin{array}{c}-0.022 \\
(-3.529)\end{array}$ & $* * *$ & $\begin{array}{c}-0.021 \\
(-3.495)\end{array}$ & $* * *$ & $\begin{array}{c}-0.022 \\
(-3.564)\end{array}$ & $* * *$ & $\begin{array}{c}-0.022 \\
(-3.565)\end{array}$ & $* * *$ & $\begin{array}{c}-0.022 \\
(-3.538)\end{array}$ & $* * *$ \\
\hline Self Employed & $\begin{array}{c}0.007 \\
(1.826)\end{array}$ & $*$ & $\begin{array}{c}0.007 \\
(1.783)\end{array}$ & $*$ & $\begin{array}{c}0.007 \\
(1.860)\end{array}$ & $*$ & $\begin{array}{c}0.008 \\
(1.915)\end{array}$ & $*$ & $\begin{array}{c}0.007 \\
(1.811)\end{array}$ & $*$ \\
\hline Retired & $\begin{array}{c}-0.018 \\
(-4.368)\end{array}$ & $* * *$ & $\begin{array}{c}-0.018 \\
(-4.308)\end{array}$ & $* * *$ & $\begin{array}{c}-0.018 \\
(-4.349)\end{array}$ & $* * *$ & $\begin{array}{c}-0.018 \\
(-4.428)\end{array}$ & $* * *$ & $\begin{array}{c}-0.018 \\
(-4.348)\end{array}$ & $* * *$ \\
\hline Unemployed & $\begin{array}{l}-0.026 \\
(-8.094)\end{array}$ & $* * *$ & $\begin{array}{l}-0.026 \\
(-8.148)\end{array}$ & $* * *$ & $\begin{array}{c}-0.026 \\
(-8.124)\end{array}$ & $* * *$ & $\begin{array}{c}-0.025 \\
(-7.987)\end{array}$ & $* * *$ & $\begin{array}{c}-0.026 \\
(-8.099)\end{array}$ & $* * *$ \\
\hline
\end{tabular}




\begin{tabular}{|c|c|c|c|c|c|c|c|c|c|c|}
\hline High School Degree & $\begin{array}{c}0.026 \\
(6.835)\end{array}$ & $* * *$ & $\begin{array}{c}0.026 \\
(6.794)\end{array}$ & $* * *$ & $\begin{array}{c}0.025 \\
(6.653)\end{array}$ & $* * *$ & $\begin{array}{c}0.025 \\
(6.595)\end{array}$ & $* * *$ & $\begin{array}{c}0.025 \\
(6.739)\end{array}$ & $* * *$ \\
\hline College Degree & $\begin{array}{c}0.112 \\
(36.635)\end{array}$ & $* * *$ & $\begin{array}{c}0.112 \\
(36.547)\end{array}$ & $* * *$ & $\begin{array}{c}0.111 \\
(36.169)\end{array}$ & $* * *$ & $\begin{array}{c}0.111 \\
(36.349)\end{array}$ & $* * *$ & $\begin{array}{c}0.112 \\
(36.370)\end{array}$ & $* * *$ \\
\hline $\begin{array}{l}\text { Political Position } \\
\text { (Right to Left) }\end{array}$ & $\begin{array}{c}-0.013 \\
(-22.791)\end{array}$ & $* * *$ & $\begin{array}{c}-0.013 \\
(-22.657)\end{array}$ & $* * *$ & $\begin{array}{c}-0.013 \\
(-22.679)\end{array}$ & $* * *$ & $\begin{array}{c}-0.013 \\
(-22.795)\end{array}$ & $* * *$ & $\begin{array}{c}-0.013 \\
(-22.629)\end{array}$ & $* * *$ \\
\hline Observations & 165,112 & & 165,112 & & 165,112 & & 165,112 & & 165,112 & \\
\hline
\end{tabular}




\section{Table $8 \quad$ Cross Sectional Probit Regressions - Regional Indicators}

The table presents marginal effects from multivariate probit regressions using the delta method for the period 1999 to 2008 . Values of the z-statistics are in parentheses. Standard errors were corrected for heteroscedasticity. ***,**,* denote significance at $1 \%, 5 \%$, and $10 \%$, respectively. The specifications account for age and political position through second-order polynomials.

\begin{tabular}{|c|c|c|c|c|}
\hline \multirow{2}{*}{ Variables } & \multicolumn{4}{|c|}{$\begin{array}{l}\text { Dependent: Trust in the European Central Bank } \\
\begin{array}{ll}\text { (1) } & \text { (2) }\end{array}\end{array}$} \\
\hline & $\begin{array}{c}\text { Marginal } \\
\text { Effects }\end{array}$ & & $\begin{array}{c}\text { Marginal } \\
\text { Effects }\end{array}$ & \\
\hline Regional GDP Growth & $\begin{array}{c}0.004 \\
(8.043)\end{array}$ & $* * *$ & $\begin{array}{c}0.001 \\
(1.716)\end{array}$ & $*$ \\
\hline Regional Unemployment Rate & $\begin{array}{c}-0.006 \\
(-20.818)\end{array}$ & $* * *$ & $\begin{array}{l}-0.003 \\
(-8.201)\end{array}$ & $* * *$ \\
\hline Age & $\begin{array}{c}0.001 \\
(10.343)\end{array}$ & $* * *$ & $\begin{array}{c}0.001 \\
(8.244)\end{array}$ & $* * *$ \\
\hline Male & $\begin{array}{c}0.022 \\
(8.206)\end{array}$ & $* * *$ & $\begin{array}{c}0.021 \\
(7.757)\end{array}$ & $* * *$ \\
\hline Couple & $\begin{array}{c}0.048 \\
(8.668)\end{array}$ & $* * *$ & $\begin{array}{c}0.048 \\
(8.629)\end{array}$ & $* * *$ \\
\hline Single & $\begin{array}{c}0.041 \\
(6.172)\end{array}$ & $* * *$ & $\begin{array}{c}0.035 \\
(5.248)\end{array}$ & $* * *$ \\
\hline Divorced & $\begin{array}{c}-0.011 \\
(-1.551)\end{array}$ & & $\begin{array}{c}-0.005 \\
(-0.772)\end{array}$ & \\
\hline Self Employed & $\begin{array}{c}-0.002 \\
(-0.370)\end{array}$ & & $\begin{array}{c}0.001 \\
(0.205)\end{array}$ & \\
\hline Retired & $\begin{array}{c}-0.011 \\
(-2.244)\end{array}$ & $* *$ & $\begin{array}{c}-0.003 \\
(-0.742)\end{array}$ & \\
\hline Unemployed & $\begin{array}{c}-0.019 \\
(-5.321)\end{array}$ & $* * *$ & $\begin{array}{c}-0.024 \\
(-6.603)\end{array}$ & $* * *$ \\
\hline High School Degree & $\begin{array}{c}0.041 \\
(9.559)\end{array}$ & $* * *$ & $\begin{array}{c}0.034 \\
(7.665)\end{array}$ & $* * *$ \\
\hline College Degree & $\begin{array}{c}0.109 \\
(30.918)\end{array}$ & $* * *$ & $\begin{array}{c}0.111 \\
(30.312)\end{array}$ & $* * *$ \\
\hline $\begin{array}{l}\text { Political Position } \\
\text { (Right to Left) }\end{array}$ & $\begin{array}{c}-0.011 \\
(-16.843) \\
\end{array}$ & $* * *$ & $\begin{array}{c}-0.011 \\
(-16.033)\end{array}$ & $* * *$ \\
\hline Country Fixed Effects & No & & Yes & \\
\hline Observations & 122,575 & & 122,575 & \\
\hline
\end{tabular}




\section{Figure 1 Trust in the European Central Bank}

The figure presents the average level of trust in the European Central Bank for selected countries of our sample.

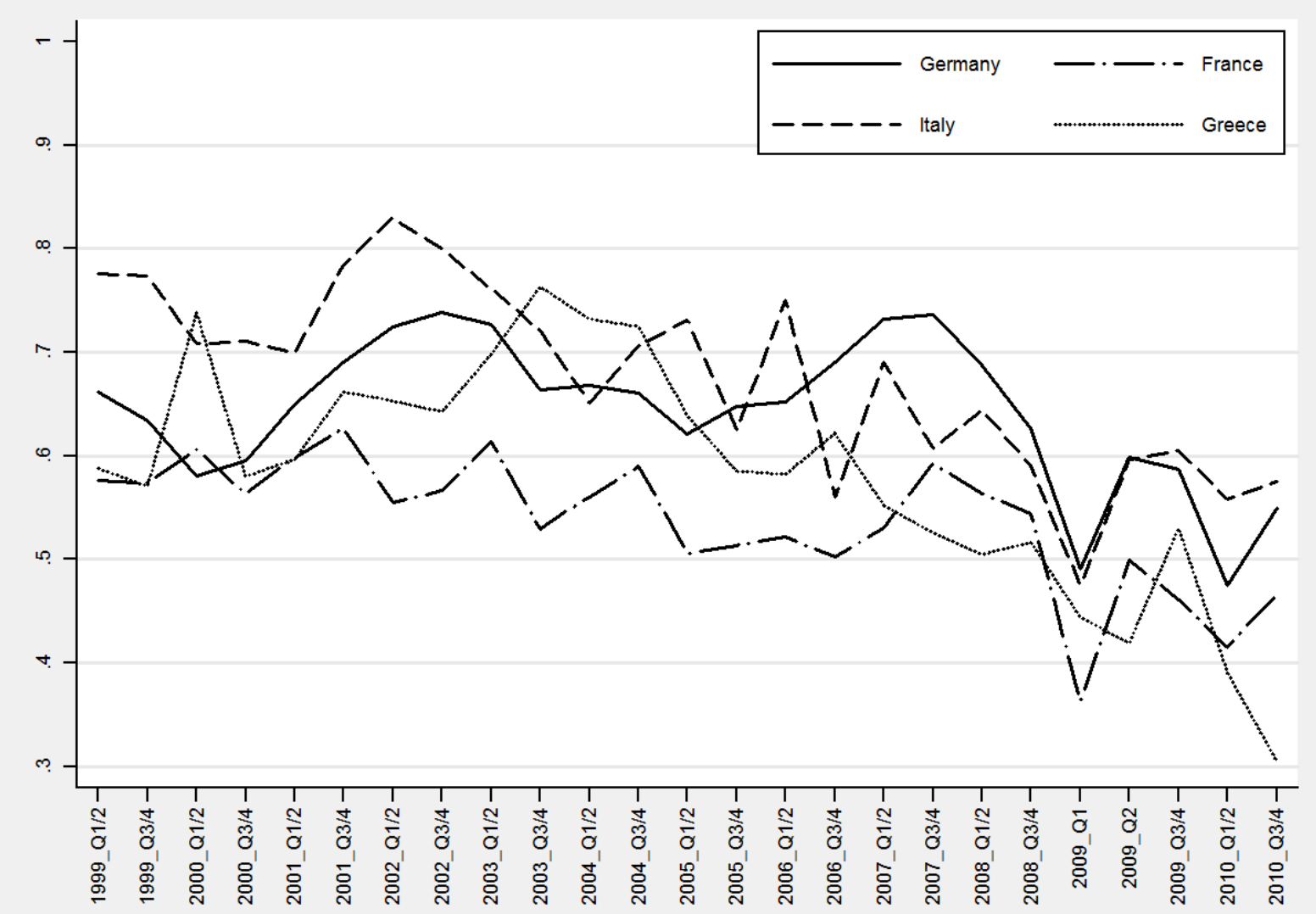




\section{Figure 2 Interaction Effect of GDP Growth}

The figure presents the calculated interaction effect of GDP Growth presented in table 7 using all stated control variables. In order to calculate the interaction effect, the methodology provided by Norton et al. (2004) is used.

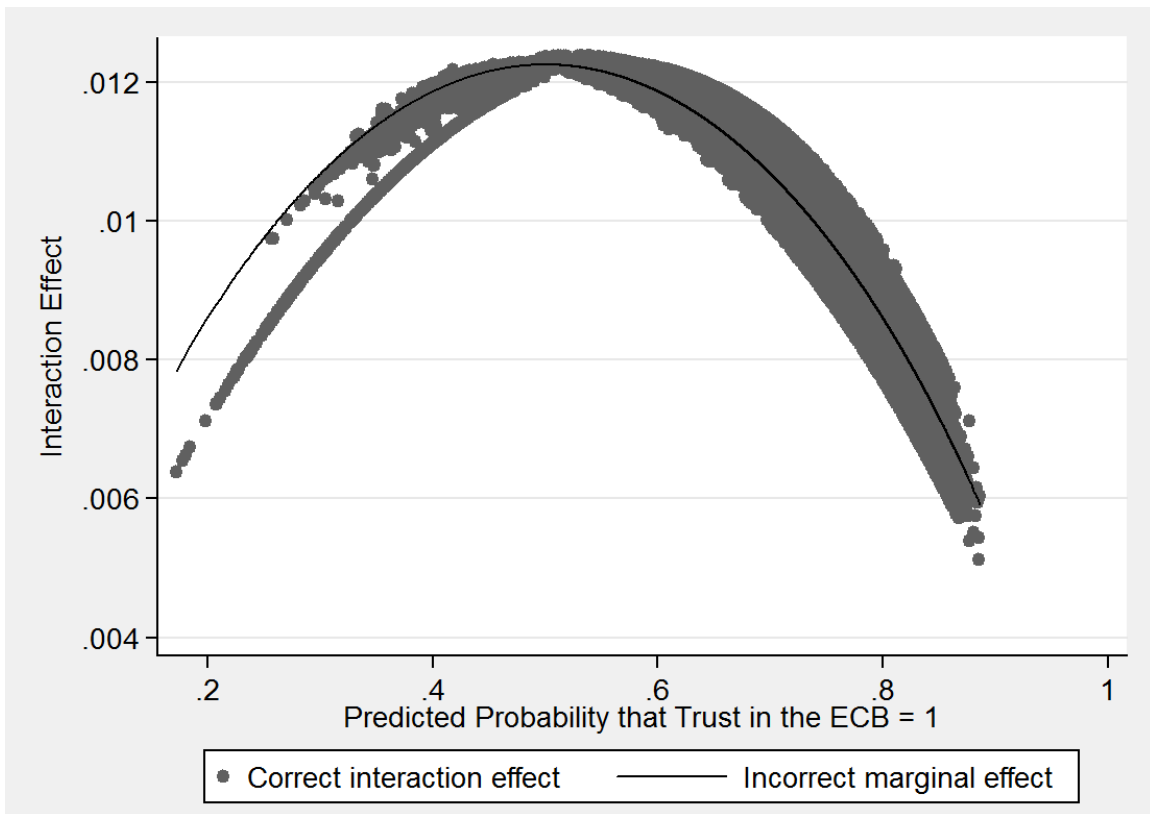

\section{Figure 3 Z-Statistic for the Interaction Effect of GDP Growth}

The figure presents the calculated z-statistics for the interaction effect of GDP Growth presented in table 7 using all stated control variables. In order to calculate the interaction effect, the methodology provided by Norton et al. (2004) is used.

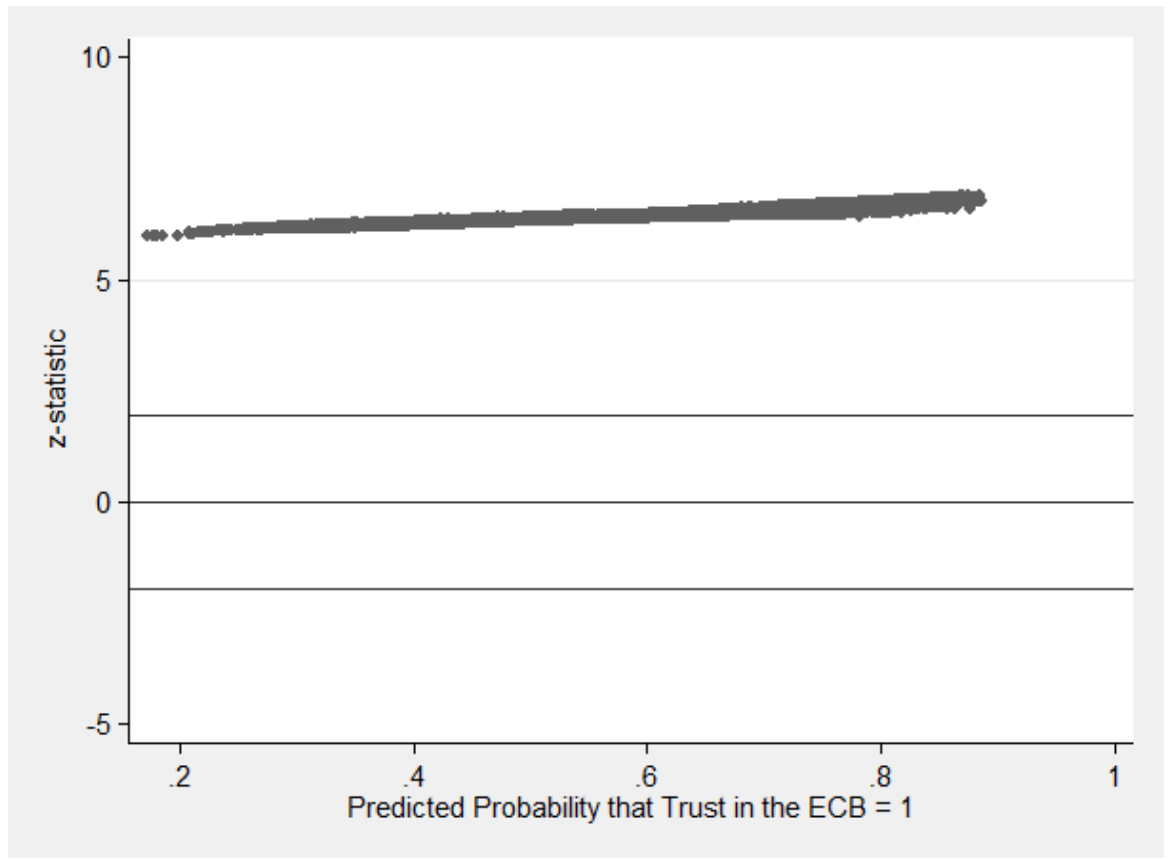




\section{Figure 4 Interaction Effect of Inflation Deviation}

The figure presents the calculated interaction effect of Inflation Deviation presented in table 7 using all stated control variables. In order to calculate the interaction effect, the methodology provided by Norton et al. (2004) is used.

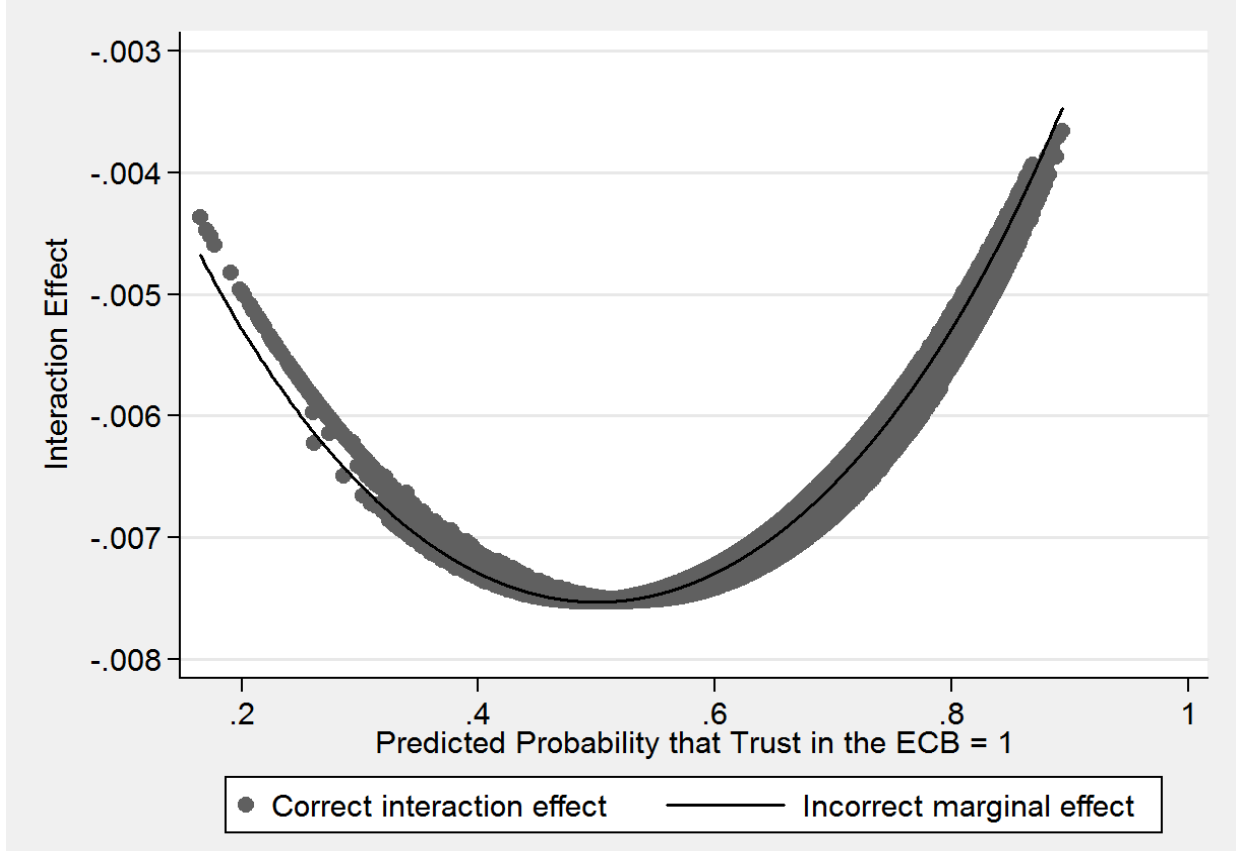

\section{Figure $5 \quad$ Z-Statistic for the Interaction Effect of Inflation Deviation}

The figure presents the calculated z-statistics for the interaction effect of Inflation Deviation presented in table 7 using all stated control variables. In order to calculate the interaction effect, the methodology provided by Norton et al. (2004) is used.

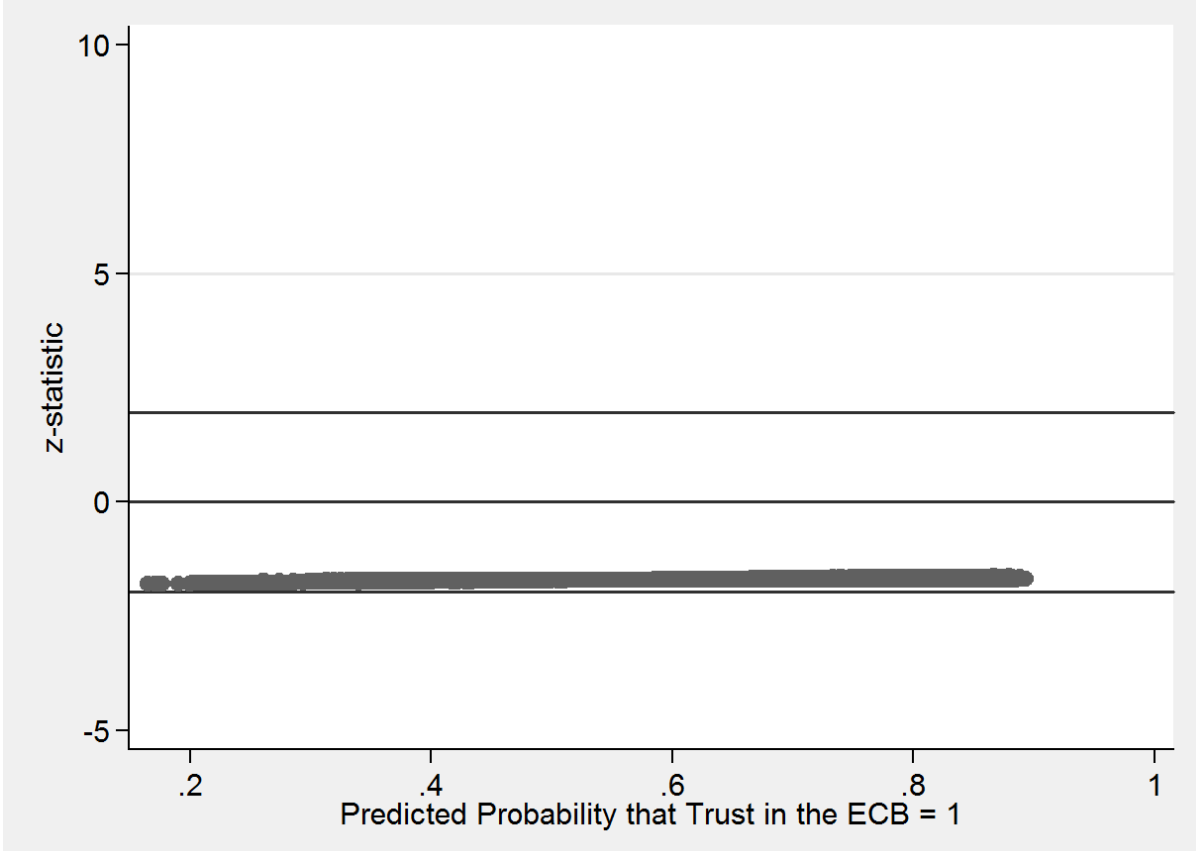




\section{Figure 6 Interaction Effect of Government Debt}

The figure presents the calculated interaction effect of Government Debt presented in table 7 using all stated control variables. In order to calculate the interaction effect, the methodology provided by Norton et al. (2004) is used.

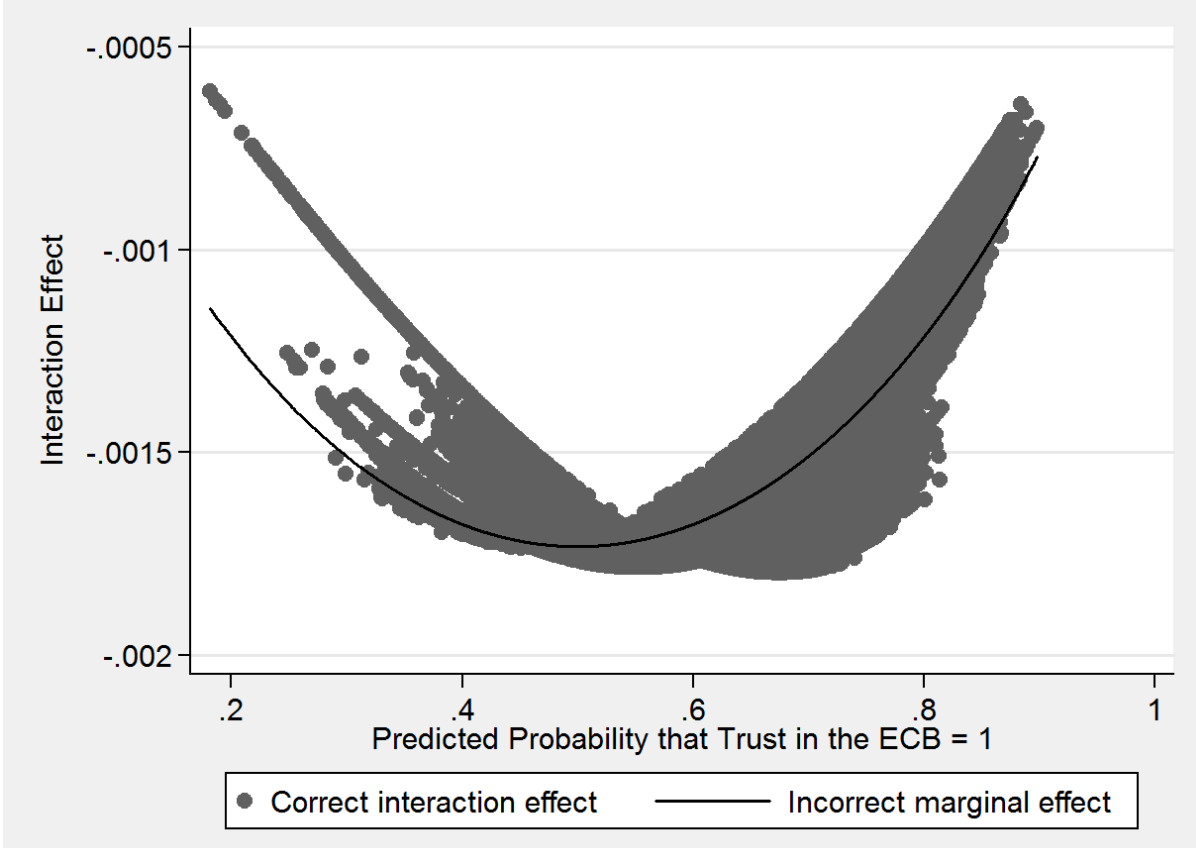

\section{Figure $7 \quad$ Z-Statistic for the Interaction Effect of Government Debt}

The figure presents the calculated z-statistics for the interaction effect of Government Debt presented in table 7 using all stated control variables. In order to calculate the interaction effect, the methodology provided by Norton et al. (2004) is used.

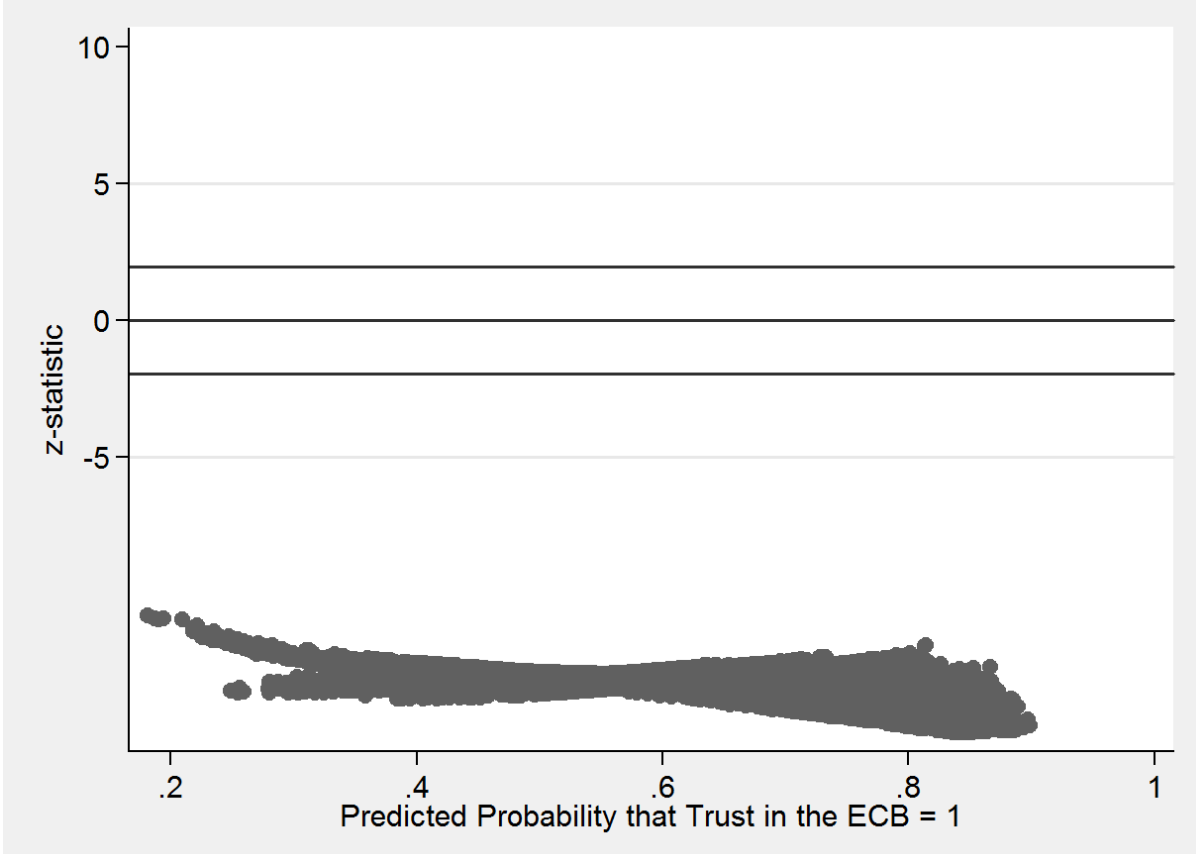




\section{Figure 8 Interaction Effect of the Government Bond Spread}

The figure presents the calculated interaction effect of Government Bond Spread presented in table 7 using all stated control variables. In order to calculate the interaction effect, the methodology provided by Norton et al. (2004) is used.

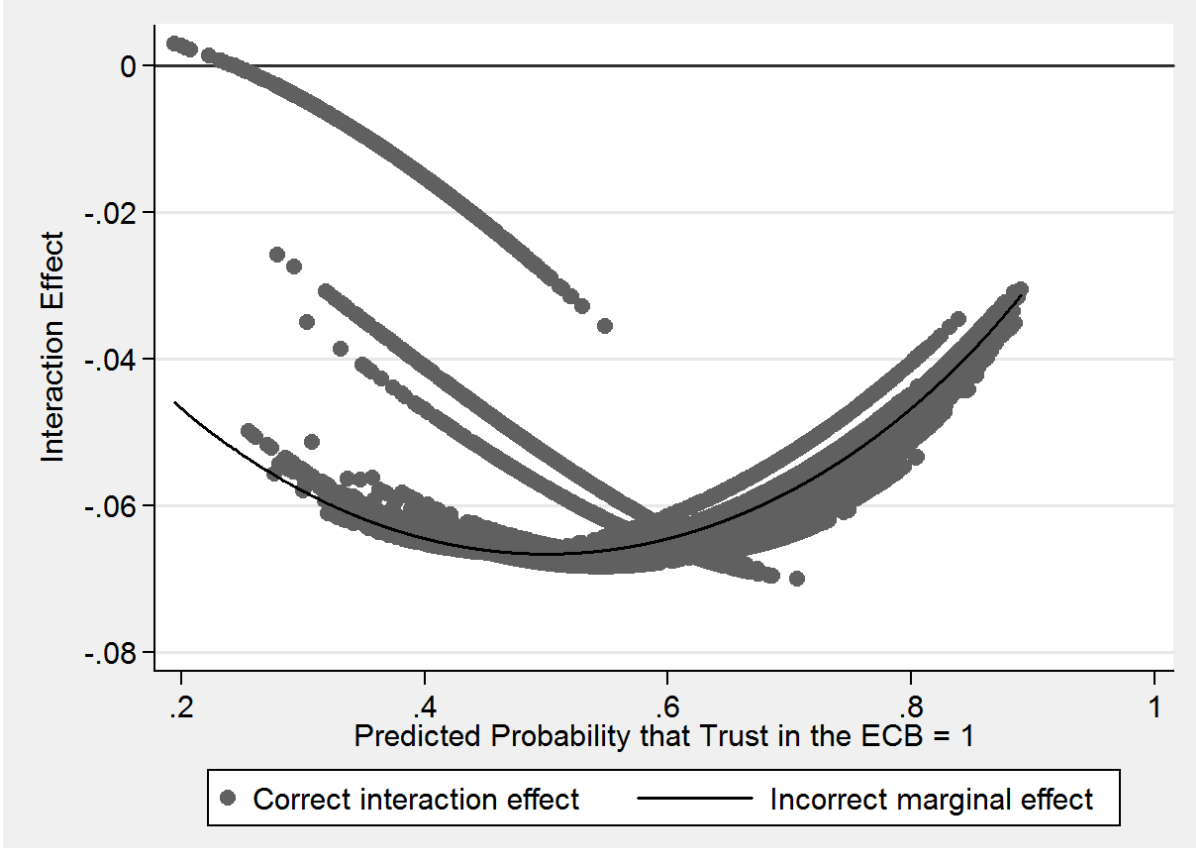

\section{Figure 9 Z-Statistic for the Interaction Effect of the Government Bond Spread}

The figure presents the calculated z-statistics for the interaction effect of Government Bond Spread presented in table 7 using all stated control variables. In order to calculate the interaction effect, the methodology provided by Norton et al. (2004) is used.

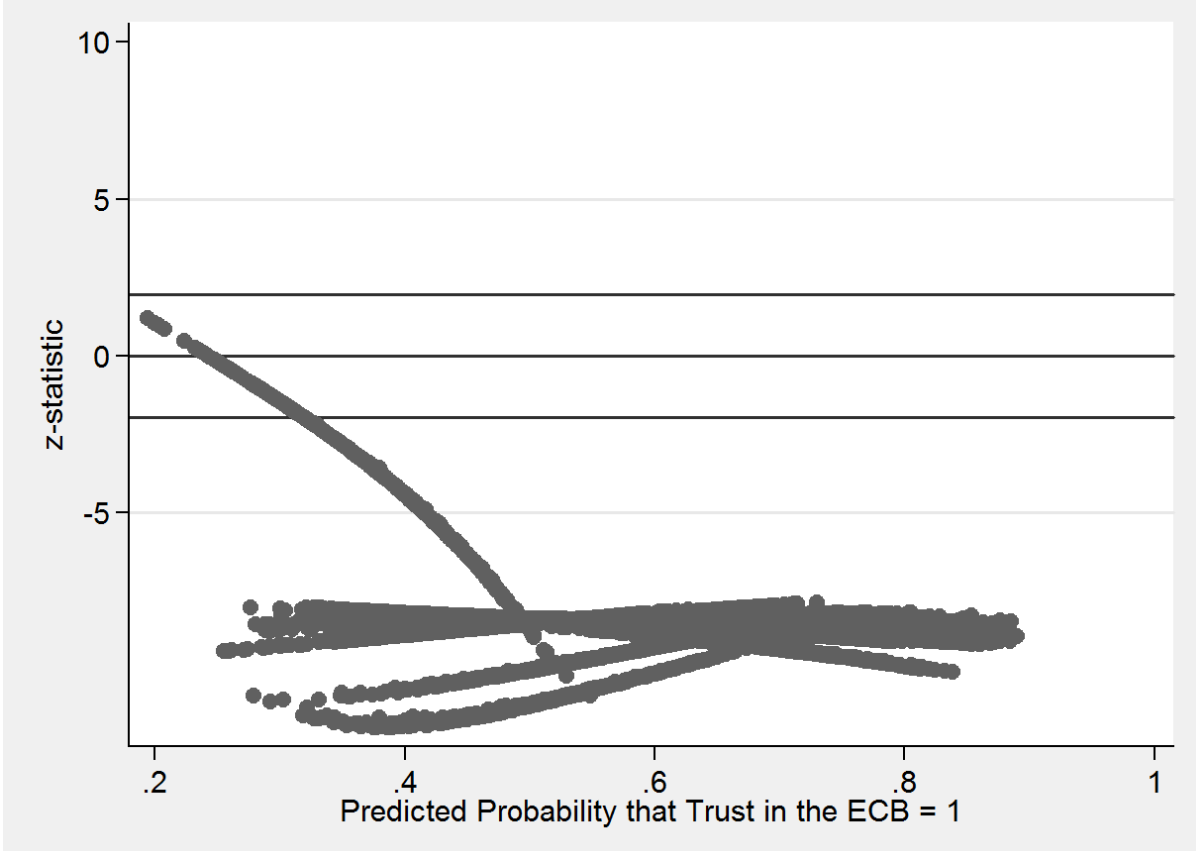




\section{Figure 10 Interaction Effect of the Unemployment Rate}

The figure presents the calculated interaction effect of Unemployment Rate presented in table 7 using all stated control variables. In order to calculate the interaction effect, the methodology provided by Norton et al. (2004) is used.

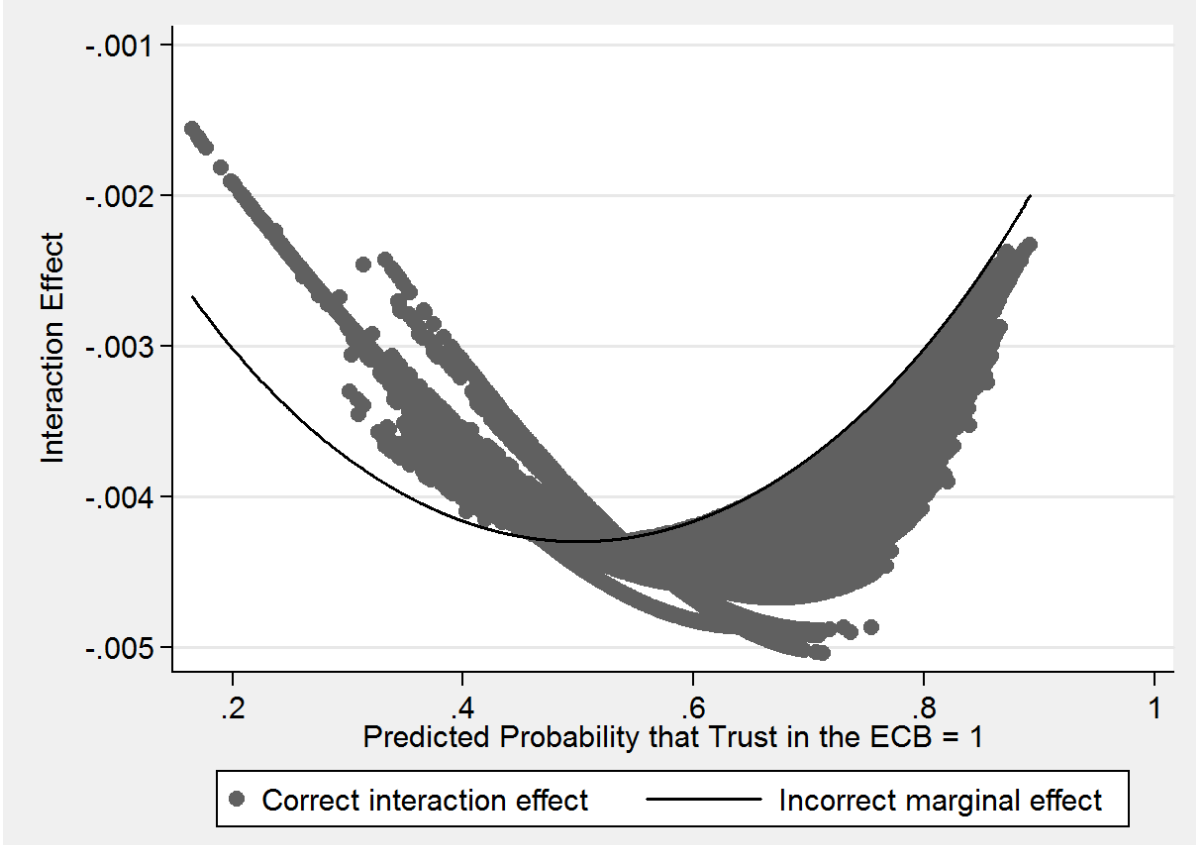

\section{Figure 11 Z-Statistic for the Interaction Effect of the Unemployment Rate}

The figure presents the calculated z-statistics for the interaction effect of Unemployment Rate presented in table 7 using all stated control variables. In order to calculate the interaction effect, the methodology provided by Norton et al. (2004) is used.

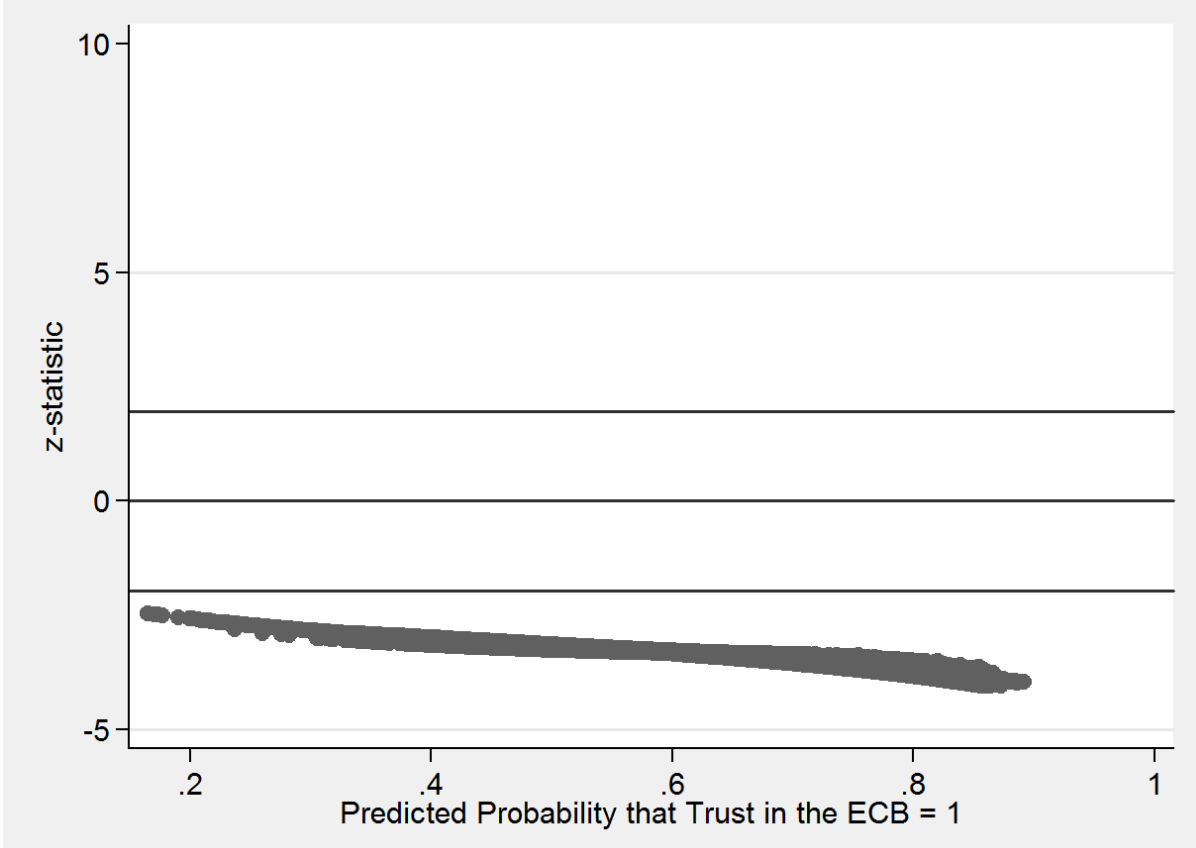




\section{APPENDIX}

The Eurobarometer is a series of surveys regularly conducted on behalf of the Public Opinion Analysis sector of the European commission since 1973. We combine a selected set of 25 Eurobarometer surveys which include our main variable of interest "Trust in the European Central Bank". The surveys are mostly conducted on a semi-annual basis. An overview of the datasets used in our study can be found below:

\begin{tabular}{lccc}
\hline Study Number & Title & Year & Version \\
\hline ZA 5449 & Eurobarometer 74.2 & 2010 & $1.1 .0,08.06 .2011$, doi: $10.4232 / 1.10707$ \\
ZA 5234 & Eurobarometer 73.4 & 2010 & $1.0 .0,23.11 .2010$, doi: $10.4232 / 1.10197$ \\
ZA 4994 & Eurobarometer 72.4 & 2009 & $2.0 .0,10.02 .2011$, doi: $10.4232 / 1.10236$ \\
ZA 4973 & Eurobarometer 71.3 & 2009 & $2.0 .0,23.11 .2010$, doi:10.4232/1.10196 \\
ZA 4971 & Eurobarometer 71.1 & 2009 & $3.0 .1,17.11 .2010$, doi:10.4232/1.10192 \\
ZA 4819 & Eurobarometer 70.1 & 2008 & $3.0 .1,17.11 .2010$, doi: $10.4232 / 1.10193$ \\
ZA 4744 & Eurobarometer 69.2 & 2008 & $3.0 .1,17.11 .2010$, doi:10.4232/1.10194 \\
ZA 4565 & Eurobarometer 68.1 & 2007 & $4.0 .0,09.09 .2010$, doi:10.4232/1.10126 \\
ZA 4530 & Eurobarometer 67.2 & 2007 & $2.0 .0,18.12 .2009$, doi: $10.4232 / 1.10068$ \\
ZA 4526 & Eurobarometer 66.1 & 2006 & $1.0 .0,13.04 .2010$, doi:10.4232/1.4526 \\
ZA 4506 & Eurobarometer 65.2 & 2006 & $1.0 .0,13.04 .2010$, doi:10.4232/1.4506 \\
ZA 4414 & Eurobarometer 64.2 & 2005 & $1.0 .0,13.04 .2010$, doi:10.4232/1.4414 \\
ZA 4411 & Eurobarometer 63.4 & 2005 & $1.0 .0,13.04 .2010$, doi:10.4232/1.4411 \\
ZA 4229 & Eurobarometer 62.0 & 2004 & $1.0 .0,13.04 .2010$, doi:10.4232/1.4229 \\
ZA 4056 & Eurobarometer 61.0 & 2004 & $1.0 .0,13.04 .2010$, doi:10.4232/1.4056 \\
ZA 3938 & Eurobarometer 60.1 & 2003 & $1.0 .0,13.04 .2010$, doi:10.4232/1.3938 \\
ZA 3904 & Eurobarometer 59.1 & 2003 & $1.0 .0,13.04 .2010$, doi:10.4232/1.3904 \\
ZA 3693 & Eurobarometer 58.1 & 2002 & $1.0 .0,13.04 .2010$, doi:10.4232/1.3693 \\
ZA 3639 & Eurobarometer 57.1 & 2002 & $1.0 .0,13.04 .2010$, doi:10.4232/1.3639 \\
ZA 3627 & Eurobarometer 56.2 & 2001 & $1.0 .0,13.04 .2010$, doi:10.4232/1.3627 \\
ZA 3507 & Eurobarometer 55.1 & 2001 & $1.0 .0,13.04 .2010$, doi:10.4232/1.3507 \\
ZA 3387 & Eurobarometer 54.1 & 2000 & $1.0 .0,13.04 .2010$, doi:10.4232/1.3387 \\
ZA 3296 & Eurobarometer 53.0 & 2000 & $1.0 .0,13.04 .2010$, doi:10.4232/1.3296 \\
ZA 3204 & Eurobarometer 52.0 & 1999 & $1.0 .0,13.04 .2010$, doi:10.4232/1.3204 \\
ZA 3171 & Eurobarometer 51.0 & 1999 & $1.0 .0,13.04 .2010$, doi:10.4232/1.3171 \\
\hline
\end{tabular}




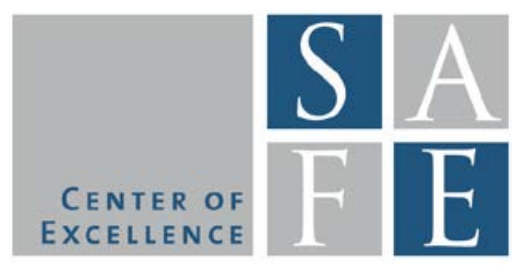

WORKING PAPER SERIES

\section{Recent Issues}

No. 30 Dirk Bursian, Markus Roth

No. 29 Iñaki Aldasoro, Ignazio Angeloni

No. 28 Nicole Branger, Holger Kraft, Christoph Meinerding

No. 27 Tobias H. Tröger

No. 26 Michael J. Brennan, Holger Kraft

No. 25 Holger Kraft, Alexander Schmidt

No. 24 Andrej Gill, Nikolai Visnjic

No. 23 Andrej Gill, Nikolai Visnjic

No. 22 Dirk Bursian, Alfons J.

Weichenrieder, Jochen Zimmer

No. 21 Stefano Corradin, Reint Gropp, Harry Huizinga, Luc Laeven

No. 20 Zeno Adams, Roland Füss, Reint Gropp

No. 19 Reint Gropp, Christian Gruendl, Andre Guettler

No. 18 Alfons J. Weichenrieder, Jochen Zimmer
Optimal policy and Taylor rule crosschecking under parameter uncertainty

Input-Output-Based Measures of Systemic Importance

Partial Information about Contagion Risk, Self-Exciting Processes and Portfolio Optimization

The Single Supervisory Mechanism Panacea or Quack Banking Regulation?

Financing Asset Growth

Systemic Risk in the Financial Sector: What Can We Learn from Option Markets?

Performance Benefits of Tight Control

Insight Private Equity

Trust in Government and Fiscal Adjustments

Who Invests in Home Equity to Exempt Wealth from Bankruptcy?

Spillover Effects among Financial Institutions: A State-Dependent Sensitivity Value-at-Risk Approach

Hidden Gems and Borrowers with Dirty Little Secrets: Investment in Soft Information, Borrower Self-selection and Competition

Euro Membership and Fiscal Reaction Functions 